\title{
ANALISIS STUDI KELAYAKAN PELAYANAN E-COMMERCE MENGGUNAKAN METODE ANALYTICAL HIERARCHY PROCESS (AHP)
}

\section{ANALYSIS OF FEASIBILITY STUDY OF E-COMMERCE SERVICES USING ANALYTICAL HIERARCHY PROCESS (AHP) METHOD}

\author{
Fifin Sonata \\ Dosen dan Peneliti Program Studi Sistem Informasi dan Teknik Informatika, Sekolah Tinggi Ilmu Komputer Medan \\ Jl. Iskandar Muda No. 45 Medan, Sumatera Utara, Indonesia \\ fifinsonata2012@gmail.com \\ Diterima : 9 Juni 2018| Direvisi : 27 Juni 2018| Disetujui : 9 Agustus 2018
}

\begin{abstract}
As part of e-commerce business activities, online buying is increasingly widespread. No need to leave the house and face the traffic jam if you want to buy goods. However the sense of consumer confidence is still an obstacle to conduct online trading transactions activities considering not meet directly with the seller. Consumers are still afraid of fraud and possible crime. E-Commerce's site also offered with a lot of display and format which can convince the consumer. From this background then this research was made analysis of feasibility study of e-commerce in serving consumer. Analytical Hierarchy Process (AHP) is one of the decision support system methods used to process and analyze the recommended e-commerce types in Indonesia. In this method will be processed into 12 criteria, that is Definite Logo, Special Offer, Free Delivery, Latest News, Popular Products, Product Brands, Shopping Cart Placements and Login, Icon System Payouts, Social Media Links, Phone Number and Chating Online, Finder Shop, Trusmark and 11 alternative types of e-commerce are Lazada, Tokopedia, Shopee, Bukalapak, Blibli, Zalora, Hijup, JD.id, Elevenia, Bhinneka, Qool0 Indonesia. Data processing by using AHP method is done by 3 principles that are Hierarchy Preparation Principle, Priority Setting Principle, Consistency Principle. The study result describes that type of e-commerce which recommended for society as an online trading consumers from the top to the lowest level are Lazada $=0,114$, Tokopedia $=0,099$, Shopee $=0,086$, Bukalapak =0,060, Blibli $=0,058$, Zalora $=0,040$, Hijup $=$ 0.038, JD.id $=0.029$, Elevenia $=0.021$, Bhinneka $=0.016$ and Qoo10 Indonesia $=0.009$. While the results of this study for the value of Consistency Ratio (CR) obtained - 0.018 atu-0.2\%. It means that optimal CR and AHP analysis are potent in the decision making process.
\end{abstract}

Keywords : AHP, alternative, e-commerce, appropriateness, criteria

\section{Abstrak}

Sebagai bagian dari aktivitas bisnis e-commerce, jual-beli online pun semakin marak dilakukan. Tidak perlu keluar rumah dan menghadapai macetnya jalan jika ingin membeli suatu barang. Tetapi walaupun demikian rasa kepercayaan konsumen masih menjadi kendala untuk melakukan kegiatan transaksi jual beli online mengingat tidak langsung bertemu dengan penjual. Konsumen masih takut akan penipuan dan hal kriminal lainnya yang mungkin terjadi. Situs e-commerce pun banyak ditawarkan dengan tampilan dan pola yang bisa meyakinkan konsumen. Dari latar belakang tersebut maka pada penelitian ini dibuat analisa studi kelayakan sebuah e-commerce dalam melakukan pelayanan kepada konsumen. Metode Analytical Hierarchy Process (AHP) adalah salah satu metode sistem pendukung keputusan yang digunakan untuk mengolah dan menganalisa jenis e-commerce yang layak direkomendasikan untuk konsumen di Indonesia. Pada metode ini akan diolah 12 kriteria yaitu Logo yang Jelas, Penawaran Khusus, Pengiriman Gratis, Berita Terbaru, Produk Popular, Merk Produk, Penempatan Shopping Cart dan Login, Pembayaran Sistem Icon, Sosial Media Link, Nomor telefon dan Chating Online, Toko Finder, Trusmark dan 11 alternatif jenis e-commerce yaitu Lazada, Tokopedia, Shopee, Bukalapak, Blibli, Zalora, Hijup, JD.id, Elevenia, Bhinneka, Qoo10 Indonesia. Pengolahan data dengan menggunakan metode AHP dilakukan dengan 3 prinsip yaitu Prinsip Penyusunan Hirarki, Prinsip Penetapan Prioritas, Prinsip Konsistensi. Hasil penelitian menunjukkan bahwa jenis e-commerce yang bisa direkomendasikan untuk masyarakat sebagai konsumen jula beli online dari urutan tertinggi sampai dengan terandah adalah Lazada $=0,114$, Tokopedia $=0,099$, Shopee $=0,086$, Bukalapak $=0,060$, Blibli $=0,058$, , Zalora $=0,040$, Hijup $=0,038, \mathrm{JD} . \mathrm{id}=0,029$, Elevenia $=0,021$, Bhinneka $=0,016$ dan Qoo10 Indonesia $=0,009$. Sedangkan hasil penelitian ini untuk nilai Consistensi Ratio (CR) didapatkan - 0,018 atu -0,2\%. Ini berarti bahwa CR optimal dan analisis AHP ampuh dalam proses pengambilan keputusan.

Kata kunci : AHP, alternatif, e-commerce, kelayakan, kriteria 


\section{PENDAHULUAN}

Penggunaan internet di Indonesia dari tahun ke tahun semakin meningkat drastis. Internet saat ini tidak hanya digunakan sebagai media komunikasi antar individu atau perorangan tetapi juga sudah merambah ke komunikasi bisnis. Hal ini disebabkan karena pasar, industri dan bisnis sedang berubah memenuhi tuntunan ekonomi dan teknologi.

Internet menawarkan berbagai sajian peluang untuk melakukan penjualan produk kebutuhan hidup sehari-hari secara langsung kepada pelanggan yang berada pada pasar konsumsi atau konsumen pada pasar industri. Sehingga banyak bermunculan bisnis e-commerce. E-commerce yaitu suatu berdagang secara online yang memanfaatkan internet dimana terdapat website yang menyediakan get dan delivery (Fadel, 2015).

Penggolongan e-commerce pada umumnya dilakukan berdasarkan sifat transaksi yaitu Business to Consumer (B2C), Business to Business (B2B), Consumer to Consumer (C2C), Peer to peer (P2P) dan Mobile Commerce (M-Commerce) (Shabur, 2015). Dan saat ini kalangan bisnis memilih menerapkan konsep e-commerce dalam memasarkan produknya. Walaupun demikian tidak serta merta bisnis e-commerce mudah dipercaya oleh konsumen karena mereka berkomunikasi secara maya sehingga semakin meningkatnya jumlah bisnis e-commerce yang ditawarkan di internet maka semakin selektif juga konsumen dalam memilih jenis e-commerce yang ditawarkan.

Untuk membantu para konsumen dalam memilih 11 bisnis e-commerce yang tepat, konsumen diharapkan tidak hanya memilih jenis $e$ commerce berdasarkan pendapat teman, intuisi dan pengalaman saja melainkan berdasarkan data, fakta dan analisa secara mendalam agar konsumen tidak dirugikan dalam bertransaksi.

Fakta yang sering didapatkan di lapangan adalah beberapa konsumen yang bertransaksi dengan e-commerce masih sering kebingungan dalam memilih jenis e-commerce karena banyaknya promo-promo yang mengiurkan. Dengan melihat kondisi yang ada maka disinilah peran Teknologi Informasi dengan metodenya sangat dibutuhkan. Salah satu metode yang dapat diterapkan dalam membantu mendukung suatu keputusan adalah Metode Analitycal Hierarchy Process (AHP). Konsep metode AHP adalah merubah nilai-nilai kualitatif menjadi nilai kuantitatif. Sehingga keputusan yang diambil bisa lebih obyektif (supriyono, 2007). Alasan metode AHP digunakan pada penelitian ini adalah AHP tidak hanya berusaha mengoptimumkan suatu tujuan tunggal seperti memaksimumkan keuntungan atau memimumkan biaya tetapi telah berubah untuk berusaha mencapai suatu tingkat keuntungan yang memuaskan atas teraihnya beberapa tujuan, misalnya tingkat keutungan yang memuaskan, tanggung jawab sosial, hubungan masyarakat, hubungan dengan serikat buruh, dan perlindungan terhadap lingkungan. Sedangkan metode sistem pendukung keputusan lain yaitu metode Simple Additive Weighting (SAW), TOPSIS dan Weight Product (WP) hanya memprioritaskan dan memaksimumkan keuntungan dan biaya dan cenderung ada bobot pada setiap kriteria yang diujikan. Metode SAW sudah pernah diimplementasikan dalam penelitian yang dilakukan oleh (fajar dkk, 2012). Tetapi penelitian hanya sebatas mengoptimasi keuntungan dan biaya. Untuk penelitian tentang metode AHP sudah pernah dilakukan oleh Anton (Anton, 2010) tentang pengambilan keputusan berdasarkan tujuan perolehan foto. Selain itu ada Faisal ( Faisal, 2015) membuat penelitian tentang sistem pendukung keputusan tentang pemilihan pemasok bahan mentah pada restoran dengan bantuan metode fuzzy dan pada penelitian yang dilakukan dengan metode AHP pada studi kasus penentuan kualitas gula tumbu. Dari beberapa penelitian yang telah dilakukan masing-masing menggunakan jenis kriteria dan alternatif yang berbeda-beda dan kompleks.

Dalam penelitian ini, metode AHP diaplikasikan pada 11 e-commerce yaitu Lazada, Tokopedia, Shopee, Bukalapak, Blibli, Zalora, Hijup, JD.id, Elevania, Bhinneka dan Qoo10 Indonesia dan 12 kriteria yang harus dimiliki oleh e-commerce yaitu Logo yang Jelas, Penawaran Khusus, Pengiriman Gratis, Berita Terbaru, Produk Popular, Merk Produk, Penempatan Shopping Cart, Login, Pembayaran Sistem Icon, Sosial Media Link, Nomor telefon dan Chating Online, Toko Finder dan Trustmark. Hasil penelitian ini dapat membantu merekomendasikan situs e-commerce yang layak untuk dipilih konsumen dalam melakukan transaksi jual beli secara online.

\section{Kajian Pustaka}

E-commerce didefinisikan sebagai proses pembelian, penjualan, mentransfer atau bertukar produk, jasa atau informasi melalui jaringan komputer melalui Internet (Mahir, 2015). 
Dengan mengambil bentuk-bentuk tradisional dari proses bisnis dan memanfaatkan jejaring sosial melalui internet, strategi bisnis dapat berhasil jika dilakukan dengan benar, yang akhirnya menghasilkan peningkatan pelanggan, kesadaran merek dan pendapatan. Keputusan pembelian pelanggan dipengaruhi oleh persepsi, motivasi, pembelajaran, sikap dan keyakinan. Persepsi dipantulkan ke pada bagaimana pelanggan memilih, mengatur, dan menginterpretasikan informasi untuk membentuk pengetahuan. Motivasi tercermin keinginan pelanggan untuk memenuhi kebutuhan mereka sendiri.

SPK merupakan sistem informasi berbasis komputer yang intraktif, fleksibel, dan dapat beradaptasi, yang secara khusus dikembangkan untuk mendukung penyelesaian permasalahan yang tidak terstruktur untuk meningkatkan pembuatan keputusan (Turban, 2001).

Metode AHP merupakan salah satu model untuk pengambilan keputusan yang dapat membantu kerangka berfikir manusia. Pada dasarnya AHP adalah metode yang memecah suatu masalah yang kompleks dan tidak terstruktur ke dalam kelompok-kelompok, mengatur kelompokkelompok tersebut ke dalam suatu susunan hirarki, memasukkan nilai numeris sebagai pengganti persepsi manusia dalam melakukan perbandingan relatif, dan akhirnya dengan suatu sintesis ditentukan elemen mana yang mempunyai prioritas tertinggi (Permadi, 1992).

Pada dasarnya langkah-langkah dalam pembentukan metode AHP dapat dijelaskan dalam algoritma berikut ini.

\section{1) Menyusun Hirarki}

Membuat struktur hirarki yang diawali dengan tujuan, dilanjutkan dengan kriteriakriteria dan kemungkinan alternatif-alternatif pada tingkatan yang paling bawah.

2) Menetapkan bobot/ prioritas elemen.

Menetapkan perbandingan berpasangan Perbandingan dilakukan berdasarkan judgment pengambil keputusan dengan menilai tingkat kepentingan suatu elemen dibandingkan elemen lain kemudian menghitung bobot/ prioritas elemen.

\section{3) Mengukur Konsistensi}

Konsistensi perlu diukur untuk mengetahui apakah penilaian atau pertimbangan yang dilakukan pada setiap langkah kedua di atas menunjukkan bahwa konsistensi antara objek yang dinilai adalah benar. AHP mengukur konsistensi menyeluruh atas berbagai pertimbangan melalui suatu rasio konsistensi. Nilai rasio konsistensi harus 0,1 atau kurang. Nilai rasio konsistensi yang melebihi 0,1 akan menyebabkan konsistensi tidak $100 \%$, disarankan untuk dilakukan perbandingan ulang pada matriksnya.

\section{METODE}

Jenis penelitian yang digunakan adalah penelitian deskriptif. Penelitian deskriptif adalah penelitian yang tujuannya untuk menyajikan data/gambaran lengkap mengenai hubungan antara fenomena yang diuji. Dimana data yang telah terkumpul kemudian disajikan kembali dengan disertai analisis sehingga dapat memberikan gambaran yang jelas. Adapun metodologi yang digunakan dalam penelitian ini digambarkan pada Gambar 1 di bawah ini:

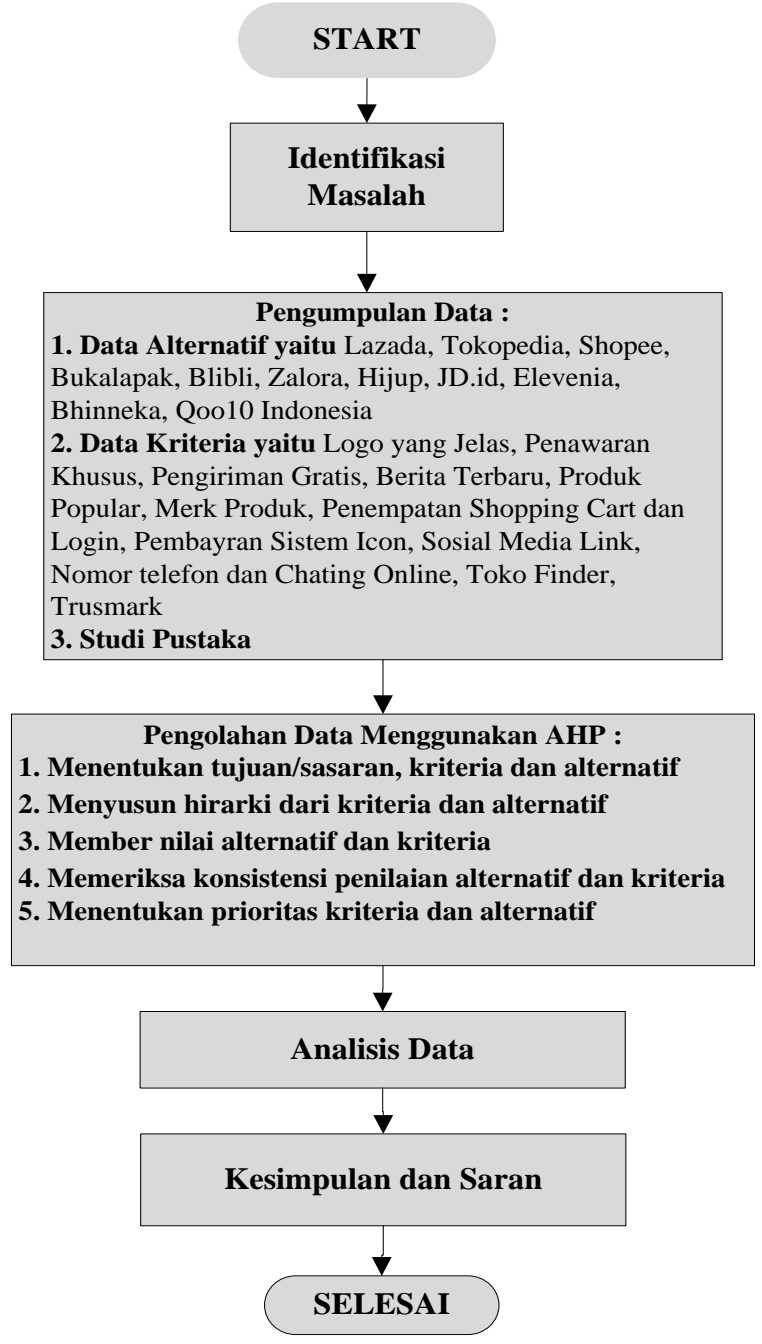

Gambar 1. Flowchart Penelitian 
Dari gambar 1 dijelaskan bahwa metodologi penelitian yang dilakukan dalam penelitian ini adalah sebagai berikut :

\section{Identifikasi Masalah}

Dimana masalah yang diidentifikasi adalah seringnya konsumen dalam memilih jenis $e$ commerce dalam melakukan transaksi jual beli online sehingga penelitian ini dibuat untuk membantu pihak konsumen dalam memilih situs $e$ commerce yang tepat dan cocok.

\section{Metode Pengumpulan Data}

Metode pengumpulan didapat dari data sekunder yang diperoleh https://toffeedev.com. Data yang diambil berupa data kriteria diantaranya :

1. Logo yang Jelas yaitu sebuah logo yang terkenal atau sebuah maskot, gambar atau video yang indah dan tombol "beli" akan mencukupi desain

2. Penawaran Khusus yaitu penawaran yang diberikan pihak e-commerce kepada konsumen pada barang-barang atau item tertentu

3. Pengiriman Gratis merupakan penawaran yang paling banyak diminati oleh konsumen. Tetapi tidak semua e-commerce melakukannya

4. Berita Terbaru yaitu situs e-commerce sering memberikan info update terkait dengan item baru dan info menarik lainnya.

5. Produk Popular yaitu bisnis e-commerce selalu mempunyai produk yang popular dikalangan masyarakat.

6. Merk Produk yaitu bisnis e-commerce banyak menawarkan merk produk sehingga konsumen awam mengetahui merk produk yang dijual oleh toko online.

7. Penempatan Shopping Cart, Login dan Search Box, yaitu penempatan icon transaksi dan menu penting yang terdapat di dalam situs. Menu situs yang mudah dipahami akan memberikan daya tarik kepada konsumen

8. Pembayaran Sistem Icon yaitu Toko online biasanya menggunakan kartu kredit dan debit, voucher hadiah, cash on delivery, PayPal sebagai sistem pembayaran utama mereka. Konsumen dapat dengan mudah menemukan ikon pembayaran di footer atau di sudut kanan atas situs.

9. Sosial Media Link yaitu apakah bisnis $e$ commerce memiliki Link ke berbagai media sosial karena media sosial merupakan tempat berkomunikasi konsumen dengan konsumen lain.
10. Nomor telefon dan Chating Online yaitu kepemilikan nomer telefon dan line chat yang dipaparkan pada situs e-commerce.

11. Toko Finder yaitu pilihan yang harus dimiliki untuk toko web yang memiliki beberapa pengecer lokal atau nasional. Banyak pelanggan konservatif yang lebih memilih untuk memeriksa sendiri toko dan dapat mengunjungi situs web hanya untuk menemukan lokasi toko terdekat atau cabangnya.

12. Trusmark yaitu gambar kecil atau logo yang menunjukkan jaminan keamanan pihak eksternal untuk menunjukkan bahwa berbelanja di situs ini aman.

Pada penelitian ini 12 Kriteria yang ada digunakan sebagai parameter karena kelayakan dalam memilih e-commerce yang tepat bisa didukung oleh 12 kriteria yang dujikan. 12 kriteria dinilai sudah cukup kompleks untuk mewakili studi kelayakan e-commerce. Selain itu metode pengumpulan data dilakukan melalui studi kepustakaan yang mencakup berbagai hal untuk memperoleh informasi data melalui jurnal terkait, website, artikel, serta literatur lain yang mendukung objek penelitian.

\section{Pengolahan Data}

Data kriteria yang dikumpulkan akan diolah menggunakan pendekatan kuantitatif dan kualitatif. Ada 11 data Alternatif yang dioleh yaitu Lazada, Tokopedia, Shopee, Bukalapak, Blibli, Zalora, Hijup, JD.id, Elevenia, Bhinneka, Qoo10 Indonesia Data-data tersebut akan disajikan dalam bentuk matriks berpasangan yang kemudian dimasukkan ke dalam perhitungan metode AHP. Sebelas data yang diolah masih berupa data kuantitatif akan diubah menjadi data kualitatif dengan prosedur yang sudah ditentukan oleh metode AHP. 11 alternatif pada penelitian ini menjadi parameter ke dua setelah kriteria. Dipilihnya 11 e-commerce ini karena berdasarkan pengamatan, 11 jasa e-commerce ini adalah situs e-commerce yang paling banyak di akses oleh konsumen di indonesia. Sehingga dengan penelitian ini parameter dipandang perlu untuk diujikan agar konsumen bisa lebih mengetahui jenis e-commerce yang layak untuk digunakan.

\section{Analisis Data}

Dalam menganalisis data menggunakan instrumen penelitian yang digunakan dalam penelitian ini adalah: 
1) Software Ms. Office, dalam hal ini yang dipergunakan adalah Microsoft word dan Excel. Microsoft word dipergunakan untuk membuat laporan penelitian serta penulisan rumus matematika.

2) Microsoft excel dipergunakan untuk melakukan perhitungan data dari kuantitatif menjadi kualitatif.

3) Software Ms. Visio. Sofware ini digunakan untuk membuat flowchart dari sebuah sistem.

\section{Metode Pengambilan keputusan dengan AHP}

Metode AHP merupakan salah satu metode dalam proses pengambilan keputusan yang dibangun berdasarkan 3 prinsip yaitu penyusunan hirarki, prinsip penetapan prioritas dan prinsip konsistensi. Berikut tahapan metode AHP:

\section{Prinsip Penyusunan Hirarki}

Tingkat teratas pada hirarki adalah fokus atau tujuan. Sedangkan tingkat dibawahnya adalah kriteria. Apabila masih bisa dipecah maka tingkat selanjutnya dinamakan sub kriteria, dan seterusnya sampai tingkatan akhir yang merupakan alternatifalternatif yang akan dipilih. Berikut adalah bentuk struktur hirarki:

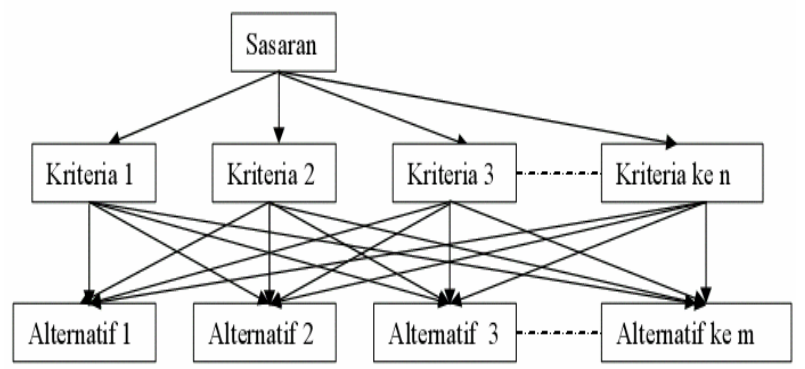

Gambar 2. Struktur Hirarki AHP Sumber: (Kirom, Bilfaqih, \& Effendie, 2012).

\section{Prinsip Penetapan Prioritas}

Penentuan prioritas dilakukan dengan cara membandingkan elemen yang satu dengan elemen yang lain kedalam bentuk matriks. Cara ini dapat disebut perbandingan berpasangan (pairwise comparison). Pada perhitungan ini, digunakan skala perbandingan 1 sampai 9. Skala perbandingan ini disebut sebagai skala fundamental, yang diturunkan berdasarkan kemampuan individu dalam membuat suatu perbandingan secara berpasangan terhadap elemen-elemen yang akan dibandingkan. Ciri metode AHP adalah melakukan pembandingan antara sepasang objek. Berikut adalah tabel skala perbandingan AHP :
Tabel 1. Skala Perbandingan AHP

\begin{tabular}{|c|c|c|}
\hline Tingkat & Definisi & Keterangan \\
\hline 1 & Sama pentingnya & $\begin{array}{l}\text { Kedua elemen memiliki } \\
\text { pengaruh yang sama }\end{array}$ \\
\hline 3 & $\begin{array}{l}\text { Agak lebih penting } \\
\text { yang satu atas yang } \\
\text { lainnya }\end{array}$ & $\begin{array}{l}\text { Pengalaman dan penilaian sangat } \\
\text { memihak satu elemen } \\
\text { dibandingkan dengan } \\
\text { pasangannya }\end{array}$ \\
\hline 5 & Cukup penting & $\begin{array}{l}\text { Pengalaman dan keputusan } \\
\text { menunjukan kesukaan atas satu } \\
\text { aktifitas lebih dari yang lain }\end{array}$ \\
\hline 7 & Sangat penting & $\begin{array}{l}\text { Pengalaman dan keputusan } \\
\text { menunjukan kesukaan yang kuat } \\
\text { atas satu aktifitas lebih dari yang } \\
\text { lain }\end{array}$ \\
\hline 9 & Mutlak lebih penting & $\begin{array}{l}\text { Satu eleman mutak lebih disukai } \\
\text { dibandingkan dengan } \\
\text { pasangannya, pada tingkat } \\
\text { keyakinan tertinggi }\end{array}$ \\
\hline $2,4,6,8$ & $\begin{array}{l}\text { Nilai tengah diantara } \\
\text { dua nilai yang } \\
\text { berdekatan }\end{array}$ & Bila kompromi dibutuhkan \\
\hline
\end{tabular}

\section{Prinsip Konsistensi}

Konsistensi metode AHP harus tetap terjaga, agar solusi yang dihasilkan optimal. Untuk mengetahui tingkat konsistensi tersebut, penggunaan metode AHP akan diukur dengan besarnya CR (Consistency Ratio). CR (Consistency Ratio) adalah hasil perbandingan antara Indeks Konsistensi (CI) dengan Indeks Random (RI). Apabila hasil CR adalah $<=0.10$ maka derajat konsistensinya optimal. Sebaiknya, jika CR adalah $>0.10$ maka terdapat ketidakkonsistenan dalam menentukan perbandingan, yang memungkinkan solusi yang dihasilkan dari metode AHP tidak berarti (Padmowati, 2009). Rasio Konsistensi diperoleh dengan langkah-langkah berikut:

Hitung $\lambda$ max

$$
\begin{aligned}
& \lambda \max =\sum_{i=1}^{n}\left\{\left[\sum_{j=1}^{n} \mathrm{a} i j\right] . \mathrm{wi}\right\} \ldots \ldots \ldots \ldots \ldots . .(1) \\
& \text { atau } \\
& \lambda \max =\sum \lambda / \mathrm{n} . \ldots \ldots \ldots \ldots \ldots \ldots \ldots \ldots \ldots \ldots \ldots . . .(2) \\
& \text { Keterangan: } \\
& \text { a }=\text { matriks } \\
& \text { w = matriks nilai eigen } \text { dalam format baris } \\
& \mathrm{n}=\text { jumlah kriteria }
\end{aligned}
$$

Hitung Indeks Konsistensi (CI)

$\mathbf{C I}=(\lambda \max -n) /(n-1)$

Keterangan:

$\mathrm{n}=$ jumlah kriteria

c. Hitung Rasio Konsistensi (CR)

$\mathbf{C R}=\mathrm{CI} / \mathrm{IRC}$

Tabel 2. Indeks Random Konsistensi (IRC)

\begin{tabular}{ll}
\hline $\mathbf{n}$ & $\mathbf{I R C}$ \\
1 & 0,00 \\
2 & 0,00 \\
3 & 0,58 \\
\hline
\end{tabular}




\begin{tabular}{cc}
\hline 4 & 0,90 \\
5 & 1,12 \\
6 & 1,24 \\
7 & 1,32 \\
8 & 1,41 \\
9 & 1,45 \\
10 & 1,49 \\
11 & 1,51 \\
\hline
\end{tabular}

Keterangan:

CI = Indeks Konsistensi/Consistency Index

IRC = Indeks Random Konsistensi

$\mathrm{n}=$ jumlah kriteria

Sumber: (Padmowati, 2009)

\section{HASIL DAN PEMBAHASAN} berikut :

Dari metode yang sudah dipaparkan maka pada pembahasan ini dimulai dengan langkah-langkah

1. Pembentukan hierarki yang digambarkan pada gambar 3 dibawah ini :

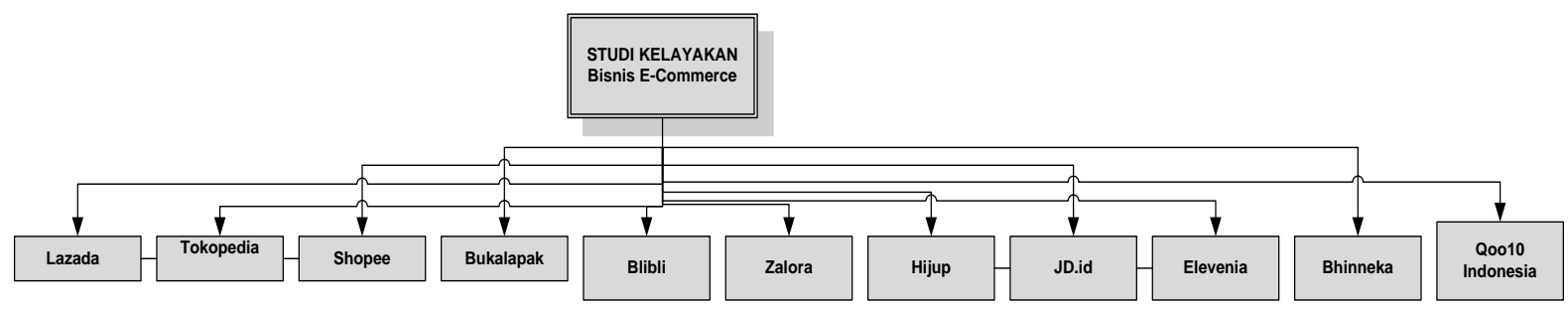

Gambar 3. Hierarki Studi Kelayakan Alternatif

2. Prinsip Penetapan Prioritas

Menentukan jenis alternatif dimana alternatif terdiri dari jenis e-commerce yang diujikan seperti yang ditabelkan pada tabel 3a sampai dengan tabel $3 \mathrm{~h}$. Tabel membentuk matriks perbandingan berpasangan. Dimana penetapan nilai prioritas diambil dari tabel 1. Pola Perhitungan pada tabel 3a sampai dengan dengan tabel $3 \mathrm{~h}$ sama. Disini akan dicontohkan perhitungan pada tabel 3a.
Nilai $1,2,4,6,8,2,4,6,8,2$, dan 4 pada baris Lazada diisi berdasarkan nilai prioritas pada tabel 1 . Dan Kolom tokopedia $=1$, 2, 4, 6, 8, 2, 4, 6, 8, dan 2. Berlaku juga pada nilai setiap kolom dari mulai Shopee sampai dengan Qoo10Indonesia. Pola perhitungan seperti yang sudah dipaparkan pada tabel $3 \mathrm{a}$ berlaku sampai dengan tabel $3 \mathrm{~h}$.

Tabel 3a. Logo yang Jelas

\begin{tabular}{lcccccccccccc}
\hline & Lazada & Tokopedia & Shopee & Bukalapak & Blibli & Zalora & Hijup & JD.id & Elevenia & $\begin{array}{c}\text { Bhinneka } \\
\text { Qoo10 } \\
\text { Indonesia }\end{array}$ \\
\hline Lazada & 1 & 2 & 4 & 6 & 8 & 2 & 4 & 6 & 8 & 2 & 4 \\
\hline Tokopedia & 0,500 & 1 & 0,500 & 0,250 & 0,167 & 0,125 & 0,500 & 0,250 & 0,167 & 0,125 & 0,500 \\
\hline Shopee & 0,250 & 2 & 1 & 2 & 4 & 6 & 8 & 2 & 4 & 6 & 8 \\
\hline Bukalapak & 0,167 & 4 & 0,500 & 1 & 0,500 & 0,250 & 0,167 & 0,125 & 0,500 & 0,250 & 0,167 \\
\hline Blibli & 0,125 & 6 & 0,250 & 2 & 1 & 2 & 4 & 6 & 8 & 2 & 4 \\
\hline Zalora & 0,500 & 8 & 0,167 & 4 & 0,500 & 1 & 0,500 & 0,500 & 0,167 & 0,125 & 0,500 \\
\hline Hijup & 0,250 & 2 & 0,125 & 6 & 0,250 & 2 & 1 & 2 & 4 & 6 & 8 \\
\hline JD.id & 0,167 & 4 & 0,500 & 8 & 0,167 & 4 & 0,500 & 1 & 0,500 & 0,250 & 0,167 \\
\hline Elevenia & 0,125 & 6 & 0,250 & 2 & 0,125 & 6 & 0,250 & 2 & 1 & 2 & 4 \\
\hline Bhinneka & 0,500 & 8 & 0,167 & 4 & 0,500 & 8 & 0,167 & 4 & 0,500 & 1 & 0,500 \\
\hline Qoo10 & & & & & & & & & & & & \\
Indonesia & 0,250 & 2 & 0,125 & 6 & 0,250 & 2 & 0,125 & 6 & 0,250 & 2 \\
\hline JUMLAH & 3,833 & 45,000 & 7,583 & 41,250 & 15,458 & 33,375 & 19,208 & 29,875 & 27,083 & 21,750 & 30,833 \\
\hline
\end{tabular}


Proses perhitungan pada tabel 3a adalah Nilai 0,500 pada baris tokopedia kolom Lazada didapat dari 1/2 $=0,500$

Nilai 0,250 pada baris Shopee kolom Lazada didapat dari $1 / 4=0,250$. Begitu seterusnya.
Nilai 0,500 pada baris tokopedia kolom Shopee didapat dari $1 / 2=0,500$

Nilai 0,167 pada baris Zalora kolom Shopee didapat dari $1 / 6=0,167$. Dan seterusnya berlaku juga pada seluruh 12 alternatif.

Tabel 3b. Penawaran Khusus

\begin{tabular}{lcccccccccccc}
\hline & Lazada & Tokopedia & Shopee & Bukalapak & Blibli & Zalora & Hijup & JD.id & Elevenia & Bhinneka $\begin{array}{c}\text { Qoo10 } \\
\text { Indonesia }\end{array}$ \\
\hline Lazada & 1 & 4 & 6 & 8 & 2 & 4 & 6 & 8 & 2 & 4 & 6 \\
\hline Tokopedia & 0,250 & 1 & 0,250 & 0,167 & 0,125 & 0,500 & 0,250 & 0,167 & 0,125 & 0,500 & 0,250 \\
\hline Shopee & 0,167 & 4 & 1 & 4 & 6 & 8 & 2 & 4 & 6 & 8 & 2 \\
\hline Bukalapak & 0,125 & 6 & 0,250 & 1 & 0,250 & 0,167 & 0,125 & 0,500 & 0,250 & 0,167 & 0,125 \\
\hline Blibli & 0,500 & 8 & 0,167 & 4 & 1 & 4 & 6 & 8 & 2 & 4 & 6 \\
\hline Zalora & 0,250 & 2 & 0,125 & 6 & 0,250 & 1 & 0,250 & 0,167 & 0,125 & 0,500 & 0,250 \\
\hline Hijup & 0,167 & 4 & 0,500 & 8 & 0,167 & 4 & 1 & 4 & 6 & 8 & 2 \\
\hline JD.id & 0,125 & 6 & 0,250 & 2 & 0,125 & 6 & 0,250 & 1 & 0,250 & 0,167 & 0,125 \\
\hline Elevenia & 0,500 & 8 & 0,167 & 4 & 0,500 & 8 & 0,167 & 4 & 1 & 4 & 6 \\
\hline Bhinneka & 0,250 & 2 & 0,125 & 6 & 0,250 & 2 & 0,125 & 6 & 0,250 & 1 & 0,250 \\
\hline Qoo10 & & & & & & & & & & & & 4 \\
Indonesia & 0,167 & 4 & 0,500 & 8 & 0,167 & 4 & 0,500 & 8 & 0,167 & 4 & 1 \\
\hline JUMLAH & 3,500 & 49,000 & 9,333 & 51,167 & 10,833 & 41,667 & 16,667 & 43,833 & 18,167 & 34,333 & 24,000 \\
\hline
\end{tabular}

Proses perhitungan pada tabel $3 \mathrm{~b}$ adalah Nilai 0,250 baris tokopedia kolom lazada didapat dari $1 / 4=$ 0,250 . Begitu seterusnya berlaku untuk baris tokopedia kolom lazada
Nilai 0,167 pada baris tokopedia kolom bukalapak didapat dari $1 / 6=0,167$. Perhitungan ini berlaku untuk pada 12 alternatif

Tabel 3c. Pengiriman Gratis

\begin{tabular}{lcccccccccccccc}
\hline & Lazada & Tokopedia & Shopee & Bukalapak & Blibli & Zalora & Hijup & JD.id & Elevenia & Bhinneka & $\begin{array}{c}\text { Qoo10 } \\
\text { Indonesia }\end{array}$ \\
\hline Lazada & 1 & 0,167 & 0,125 & 0,500 & 0,250 & 0,167 & 0,125 & 0,167 & 0,125 & 0,500 & 0,167 \\
\hline Tokopedia & 6 & 1 & 6 & 8 & 2 & 4 & 6 & 8 & 6 & 8 & 2 \\
\hline Shopee & 8 & 0,167 & 1 & 0,167 & 0,125 & 0,500 & 0,250 & 0,167 & 0,125 & 0,167 & 0,125 \\
\hline Bukalapak & 2 & 0,125 & 6 & 1 & 6 & 8 & 2 & 4 & 6 & 8 & 6 \\
\hline Blibli & 4 & 0,500 & 8 & 0,167 & 1 & 0,167 & 0,125 & 0,500 & 0,250 & 0,167 & 0,125 \\
\hline Zalora & 6 & 0,250 & 2 & 0,125 & 6 & 1 & 6 & 8 & 2 & 4 & 6 \\
\hline Hijup & 8 & 0,167 & 4 & 0,500 & 8 & 0,167 & 1 & 0,167 & 0,125 & 0,500 & 0,250 \\
\hline JD.id & 6 & 0,125 & 6 & 0,250 & 2 & 0,125 & 6 & 1 & 6 & 8 & 2 \\
\hline Elevenia & 8 & 0,167 & 8 & 0,167 & 4 & 0,500 & 8 & 0,167 & 1 & 0,167 & 0,125 \\
\hline Bhinneka & 2 & 0,125 & 6 & 0,125 & 6 & 0,250 & 2 & 0,125 & 6 & 1 & 0,167 \\
\hline Qoo10 & & & 0,500 & 8 & 0,167 & 8 & 0,167 & 4 & 0,500 & 8 & 6 \\
Indonesia & 6 & 3,292 & 55,125 & 11,167 & 43,375 & 15,042 & 35,500 & 22,792 & 35,625 & 36,500 & 17,958 \\
\hline JUMLAH & 57,000 & 3 & & & & & & & & & & \\
\hline
\end{tabular}

Pada tabel $3 \mathrm{c}$ nilai 0,125 pada baris Bhinneka kolom tokopedia didapat dari $1 / 8=0,125$. Berlaku untuk semua alternatif. Nilai jumlah didapatkan dari penjumlahan seluruh kolom. Contoh untuk nilai jumlah $57,000=1+6+8+2+4+6+8+6+8+2+6$, $3,292=0,167+1+0,167+0,125+0,125+0,500+0,250+$ $0,167+0,125+0,167+0,125+0,500$

Tabel 3d. Berita Terbaru

\begin{tabular}{lccccccccccc}
\hline & Lazada & Tokopedia & Shopee & Bukalapak & Blibli & Zalora & Hijup & JD.id & Elevenia & Bhinneka $\begin{array}{c}\text { Qoo10 } \\
\text { Indonesia }\end{array}$ \\
\hline Lazada & 1 & 0,125 & 0,500 & 0,250 & 0,167 & 0,125 & 0,500 & 0,250 & 0,167 & 0,125 & 0,500 \\
\hline Tokopedia & 8 & 1 & 8 & 2 & 4 & 6 & 8 & 2 & 4 & 6 & 8 \\
\hline Shopee & 2 & 0,125 & 1 & 0,125 & 0,500 & 0,250 & 0,167 & 0,125 & 0,500 & 0,250 & 0,167 \\
\hline Bukalapak & 4 & 0,500 & 8 & 1 & 8 & 2 & 4 & 6 & 8 & 2 & 4 \\
\hline Blibli & 6 & 0,250 & 2 & 0,125 & 1 & 0,125 & 0,500 & 0,250 & 0,167 & 0,125 & 0,500 \\
\hline Zalora & 8 & 0,167 & 4 & 0,500 & 8 & 1 & 8 & 2 & 4 & 6 & 8 \\
\hline Hijup & 2 & 0,125 & 6 & 0,250 & 2 & 0,125 & 1 & 0,125 & 0,500 & 0,250 & 0,167 \\
\hline
\end{tabular}




\begin{tabular}{lcccccccccccc}
\hline JD.id & 4 & 0,500 & 8 & 0,167 & 4 & 0,500 & 8 & 1 & 8 & 2 & 4 \\
\hline Elevenia & 6 & 0,250 & 2 & 0,125 & 6 & 0,250 & 2 & 0,125 & 1 & 0,125 & 0,500 \\
\hline Bhinneka & 8 & 0,167 & 4 & 0,500 & 8 & 0,167 & 4 & 0,500 & 8 & 1 & 0,125 \\
\hline Qoo10 & & & & & & & & & & & \\
Indonesia & 2 & 0,125 & 6 & 0,250 & 2 & 0,125 & 6 & 0,250 & 2 & 8 & 1 \\
\hline JUMLAH & 51,000 & 3,333 & 49,500 & 5,292 & 43,667 & 10,667 & 42,167 & 12,625 & 36,333 & 25,875 & 26,958 \\
\hline
\end{tabular}

Proses perhitungan pada tabel $3 \mathrm{~d}$ sampai dengan $3 \mathrm{~h}$ sama dengan perhitungan pada tabel $3 \mathrm{a}$ sampai dengan $3 d$.

Tabel 3e. Pembayaran sistem Icon

\begin{tabular}{lccccccccccccccc}
\hline & Lazada & Tokopedia & Shopee & Bukalapak & Blibli & Zalora & Hijup & JD.id & Elevenia & Bhinneka $\begin{array}{c}\text { Qoo10 10 } \\
\text { Indonesia }\end{array}$ \\
\hline Lazada & 1 & 0,167 & 0,250 & 0,500 & 0,125 & 0,167 & 0,250 & 0,500 & 0,125 & 0,167 & 0,250 \\
\hline Tokopedia & 6 & 1 & 6 & 4 & 2 & 8 & 6 & 4 & 2 & 8 & 6 \\
\hline Shopee & 4 & 0,167 & 1 & 0,167 & 0,250 & 0,500 & 0,125 & 0,167 & 0,250 & 0,500 & 0,125 \\
\hline Bukalapak & 2 & 0,250 & 6 & 1 & 6 & 4 & 2 & 8 & 6 & 4 & 2 \\
\hline Blibli & 8 & 0,500 & 4 & 0,167 & 1 & 0,167 & 0,250 & 0,500 & 0,125 & 0,167 & 0,250 \\
\hline Zalora & 6 & 0,125 & 2 & 0,250 & 6 & 1 & 6 & 4 & 2 & 8 & 6 \\
\hline Hijup & 4 & 0,167 & 8 & 0,500 & 4 & 0,167 & 1 & 0,167 & 0,250 & 0,500 & 0,125 \\
\hline JD.id & 2 & 0,250 & 6 & 0,125 & 2 & 0,250 & 6 & 1 & 6 & 4 & 2 \\
\hline Elevenia & 8 & 0,500 & 4 & 0,167 & 8 & 0,500 & 4 & 0,167 & 1 & 0,167 & 0,250 \\
\hline Bhinneka & 6 & 0,125 & 2 & 0,250 & 6 & 0,125 & 2 & 0,250 & 6 & 1 & 6 \\
\hline Qoo10 & & & & & & & & & & & & & & \\
Indonesia & 4 & 0,167 & 8 & 0,500 & 4 & 0,167 & 8 & 0,500 & 4 & 0,167 & 1 \\
\hline JUMLAH & 51,000 & 3,417 & 47,250 & 7,625 & 39,375 & 15,042 & 35,625 & 19,250 & 27,750 & 26,667 & 24,000 \\
\hline
\end{tabular}

Tabel 3f. Sosial Media Link

\begin{tabular}{lcccccccccccc}
\hline & Lazada & Tokopedia & Shopee & Bukalapak & Blibli & Zalora & Hijup & JD.id & Elevenia & Bhinneka $\begin{array}{c}\text { Qoo10 } \\
\text { Indonesia }\end{array}$ \\
\hline Lazada & 1 & 6 & 4 & 2 & 8 & 6 & 4 & 2 & 8 & 6 & 4 \\
\hline Tokopedia & 0,167 & 1 & 0,167 & 0,250 & 0,500 & 0,125 & 0,167 & 0,250 & 0,500 & 0,125 & 0,167 \\
\hline Shopee & 0,250 & 6 & 1 & 6 & 4 & 2 & 8 & 6 & 4 & 2 & 8 \\
\hline Bukalapak & 0,500 & 4 & 0,167 & 1 & 0,167 & 0,250 & 0,500 & 0,125 & 0,167 & 0,250 & 0,500 \\
\hline Blibli & 0,125 & 2 & 0,250 & 6 & 1 & 6 & 4 & 2 & 8 & 6 & 4 \\
\hline Zalora & 0,167 & 8 & 0,500 & 4 & 0,167 & 1 & 0,167 & 0,250 & 0,500 & 0,125 & 0,167 \\
\hline Hijup & 0,250 & 6 & 0,125 & 2 & 0,250 & 6 & 1 & 6 & 4 & 2 & 8 \\
\hline JD.id & 0,500 & 4 & 0,167 & 8 & 0,500 & 4 & 0,167 & 1 & 0,167 & 0,250 & 0,500 \\
\hline Elevenia & 0,125 & 2 & 0,250 & 6 & 0,125 & 2 & 0,250 & 6 & 1 & 6 & 4 \\
\hline Bhinneka & 0,167 & 8 & 0,500 & 4 & 0,167 & 8 & 0,500 & 4 & 0,167 & 1 & 0,167 \\
\hline Qoo10 & & & & & & & & & & & \\
Indonesia & 0,250 & 6 & 0,125 & 2 & 0,250 & 6 & 0,125 & 2 & 0,250 & 6 \\
\hline JUMLAH & 3,500 & 53,000 & 7,250 & 41,250 & 15,125 & 41,375 & 18,875 & 29,625 & 26,750 & 29,750 & 30,500 \\
\hline
\end{tabular}

Tabel 3g. Toko Finder

\begin{tabular}{lcccccccccccc}
\hline & Lazada & Tokopedia & Shopee & Bukalapak & Blibli & Zalora & Hijup & JD.id & Elevenia & Bhinneka $\begin{array}{c}\text { Qoo10 } \\
\text { Indonesia }\end{array}$ \\
\hline Lazada & 1 & 0,125 & 0,500 & 0,250 & 0,167 & 0,125 & 0,500 & 0,250 & 0,167 & 0,125 & 0,500 \\
\hline Tokopedia & 8 & 1 & 8 & 2 & 4 & 6 & 8 & 2 & 4 & 6 & 8 \\
\hline Shopee & 2 & 0,125 & 1 & 0,125 & 0,500 & 0,250 & 0,167 & 0,125 & 0,500 & 0,250 & 0,167 \\
\hline Bukalapak & 4 & 0,500 & 8 & 1 & 8 & 2 & 4 & 6 & 8 & 2 & 4 \\
\hline Blibli & 6 & 0,250 & 2 & 0,125 & 1 & 0,125 & 0,500 & 0,250 & 0,167 & 0,125 & 0,500 \\
\hline Zalora & 8 & 0,167 & 4 & 0,500 & 8 & 1 & 8 & 2 & 4 & 6 & 8 \\
\hline Hijup & 2 & 0,125 & 6 & 0,250 & 2 & 0,125 & 1 & 0,125 & 0,500 & 0,250 & 0,167 \\
\hline JD.id & 4 & 0,500 & 8 & 0,167 & 4 & 0,500 & 8 & 1 & 8 & 2 & 4 \\
\hline Elevenia & 6 & 0,250 & 2 & 0,125 & 6 & 0,250 & 2 & 0,125 & 1 & 0,125 & 0,500 \\
\hline Bhinneka & 8 & 0,167 & 4 & 0,500 & 8 & 0,167 & 4 & 0,500 & 8 & 1 & 0,125 \\
\hline Qoo10 & & & & & & & & & & & \\
Indonesia & 2 & 0,125 & 6 & 0,250 & 2 & 0,125 & 6 & 0,250 & 2 & 8 \\
\hline JUMLAH & 51,000 & 3,333 & 49,500 & 5,292 & 43,667 & 10,667 & 42,167 & 12,625 & 36,333 & 25,875 & 26,958 \\
\hline
\end{tabular}


Setelah memasukkan data dan menjumlahkan nilai setiap kolom pada tabel 3a sampai dengan $3 \mathrm{~h}$ selanjutnya dilakukan proses pembagian antara jumlah setiap kolom aternatif dengan masing-masing nilai alternatif yang dapat dilihat pada tabel 4a sampai dengan $4 \mathrm{~h}$.

Tabel 4a. Logo yang Jelas

\begin{tabular}{lccccccccccc}
\hline & Lazada & Tokopedia & Shopee & Bukalapak & Blibli & Zalora & Hijup & JD.id & Elevenia & Bhinneka $\begin{array}{c}\text { Qoo10 } \\
\text { Indonesia }\end{array}$ \\
\hline Lazada & 0,261 & 0,044 & 0,527 & 0,145 & 0,518 & 0,060 & 0,208 & 0,201 & 0,295 & 0,092 & 0,130 \\
\hline Tokopedia & 0,130 & 0,022 & 0,066 & 0,006 & 0,011 & 0,004 & 0,026 & 0,008 & 0,006 & 0,006 & 0,016 \\
\hline Shopee & 0,065 & 0,044 & 0,132 & 0,048 & 0,259 & 0,180 & 0,416 & 0,067 & 0,148 & 0,276 & 0,259 \\
\hline Bukalapak & 0,043 & 0,089 & 0,066 & 0,024 & 0,032 & 0,007 & 0,009 & 0,004 & 0,018 & 0,011 & 0,005 \\
\hline Blibli & 0,033 & 0,133 & 0,033 & 0,048 & 0,065 & 0,060 & 0,208 & 0,201 & 0,295 & 0,092 & 0,130 \\
\hline Zalora & 0,130 & 0,178 & 0,022 & 0,097 & 0,032 & 0,030 & 0,026 & 0,017 & 0,006 & 0,006 & 0,016 \\
\hline Hijup & 0,065 & 0,044 & 0,016 & 0,145 & 0,016 & 0,060 & 0,052 & 0,067 & 0,148 & 0,276 & 0,259 \\
\hline JD.id & 0,043 & 0,089 & 0,066 & 0,194 & 0,011 & 0,120 & 0,026 & 0,033 & 0,018 & 0,011 & 0,005 \\
\hline Elevenia & 0,033 & 0,133 & 0,033 & 0,048 & 0,008 & 0,180 & 0,013 & 0,067 & 0,037 & 0,092 & 0,130 \\
\hline Bhinneka & 0,130 & 0,178 & 0,022 & 0,097 & 0,032 & 0,240 & 0,009 & 0,134 & 0,018 & 0,046 & 0,016 \\
\hline Qoo10 & & & & & & & & & & & \\
Indonesia & 0,065 & 0,044 & 0,016 & 0,145 & 0,016 & 0,060 & 0,007 & 0,201 & 0,009 & 0,092 & 0,032 \\
\hline
\end{tabular}

Pada tabel 4a nilai 0,261 diperoleh dari nilai 1 pada kolom lazada baris lazada pada kolom 3a dibagi dengan jumlah pada kolom lazada di tabel 3 a yaitu
$1 / 3,3833=0,261$. Perhitunganga ini berlaku untuk semua nilai pada tabel $4 \mathrm{~b}$ sampai dengan $4 \mathrm{~h}$.

Nilai Tabel 4b. Penawaran Khusus

\begin{tabular}{lcccccccccccc}
\hline & Lazada & Tokopedia & Shopee & Bukalapak & Blibli & Zalora & Hijup & JD.id & Elevenia & Bhinneka & $\begin{array}{c}\text { Qoo10 } \\
\text { Indonesia }\end{array}$ \\
\hline Lazada & 0,286 & 0,082 & 0,643 & 0,156 & 0,185 & 0,096 & 0,360 & 0,183 & 0,110 & 0,117 & 0,250 \\
\hline Tokopedia & 0,071 & 0,020 & 0,027 & 0,003 & 0,012 & 0,012 & 0,015 & 0,004 & 0,007 & 0,015 & 0,010 \\
\hline Shopee & 0,048 & 0,082 & 0,107 & 0,078 & 0,554 & 0,192 & 0,120 & 0,091 & 0,330 & 0,233 & 0,083 \\
\hline Bukalapak & 0,036 & 0,122 & 0,027 & 0,020 & 0,023 & 0,004 & 0,008 & 0,011 & 0,014 & 0,005 & 0,005 \\
\hline Blibli & 0,143 & 0,163 & 0,018 & 0,078 & 0,092 & 0,096 & 0,360 & 0,183 & 0,110 & 0,117 & 0,250 \\
\hline Zalora & 0,071 & 0,041 & 0,013 & 0,117 & 0,023 & 0,024 & 0,015 & 0,004 & 0,007 & 0,015 & 0,010 \\
\hline Hijup & 0,048 & 0,082 & 0,054 & 0,156 & 0,015 & 0,096 & 0,060 & 0,091 & 0,330 & 0,233 & 0,083 \\
\hline JD.id & 0,036 & 0,122 & 0,027 & 0,039 & 0,012 & 0,144 & 0,015 & 0,023 & 0,014 & 0,005 & 0,005 \\
\hline Elevenia & 0,143 & 0,163 & 0,018 & 0,078 & 0,046 & 0,192 & 0,010 & 0,091 & 0,055 & 0,117 & 0,250 \\
\hline Bhinneka & 0,071 & 0,041 & 0,013 & 0,117 & 0,023 & 0,048 & 0,008 & 0,137 & 0,014 & 0,029 & 0,010 \\
\hline Qoo10 & & & & & & & & & & & \multirow{2}{*}{0,117} & 0,042 \\
Indonesia & 0,048 & 0,082 & 0,054 & 0,156 & 0,015 & 0,096 & 0,030 & 0,183 & 0,009 & 0,117 \\
\hline
\end{tabular}

Pada tabel $4 \mathrm{c}$ perhitungan dari nilai 0,286 didapat dari pembagian dari 1 dibanding dengan 0,500 pada tabel 3b. Penawaran Khusus.

Tabel 4c. Berita Terbaru

\begin{tabular}{lccccccccccc}
\hline & Lazada & Tokopedia & Shopee & Bukalapak & Blibli & Zalora & Hijup & JD.id & Elevenia & $\begin{array}{c}\text { Bhinneka } \\
\text { Qoo10 } \\
\text { Indonesia }\end{array}$ \\
Lazada & 0,020 & 0,038 & 0,010 & 0,047 & 0,004 & 0,012 & 0,012 & 0,020 & 0,005 & 0,005 & 0,019 \\
Tokopedia & 0,157 & 0,300 & 0,162 & 0,378 & 0,092 & 0,563 & 0,190 & 0,158 & 0,110 & 0,232 & 0,297 \\
Shopee & 0,039 & 0,038 & 0,020 & 0,024 & 0,011 & 0,023 & 0,004 & 0,010 & 0,014 & 0,010 & 0,006 \\
Bukalapak & 0,078 & 0,150 & 0,162 & 0,189 & 0,183 & 0,188 & 0,095 & 0,475 & 0,220 & 0,077 & 0,148 \\
Blibli & 0,118 & 0,075 & 0,040 & 0,024 & 0,023 & 0,012 & 0,012 & 0,020 & 0,005 & 0,005 & 0,019 \\
Zalora & 0,157 & 0,050 & 0,081 & 0,094 & 0,183 & 0,094 & 0,190 & 0,158 & 0,110 & 0,232 & 0,297 \\
Hijup & 0,039 & 0,038 & 0,121 & 0,047 & 0,046 & 0,012 & 0,024 & 0,010 & 0,014 & 0,010 & 0,006 \\
JD.id & 0,078 & 0,150 & 0,162 & 0,031 & 0,092 & 0,047 & 0,190 & 0,079 & 0,220 & 0,077 & 0,148 \\
Elevenia & 0,118 & 0,075 & 0,040 & 0,024 & 0,137 & 0,023 & 0,047 & 0,010 & 0,028 & 0,005 & 0,019 \\
Bhinneka & 0,157 & 0,050 & 0,081 & 0,094 & 0,183 & 0,016 & 0,095 & 0,040 & 0,220 & 0,039 & 0,005 \\
Qoo10 & & & & & & & & & & & \\
Indonesia & 0,039 & 0,038 & 0,121 & 0,047 & 0,046 & 0,012 & 0,142 & 0,020 & 0,055 & 0,309 & 0,037 \\
\hline
\end{tabular}


Perhitungan semua nilai yang terdapat pada tabel $4 \mathrm{c}, 4 \mathrm{~d}$ dan $4 \mathrm{e}$ mempunyai pola yang sama dengan perhitungan pada tabel $4 \mathrm{c}$.

Tabel 4d. Merk Popular

\begin{tabular}{lccccccccccc}
\hline & Lazada & Tokopedia & Shopee & Bukalapak & Blibli & Zalora & Hijup & JD.id & Elevenia & Bhinneka $\begin{array}{c}\text { Qoo10 } \\
\text { Indonesia }\end{array}$ \\
\hline Lazada & 0,261 & 0,043 & 0,545 & 0,127 & 0,539 & 0,106 & 0,291 & 0,239 & 0,088 & 0,144 & 0,213 \\
\hline Tokopedia & 0,130 & 0,021 & 0,034 & 0,004 & 0,008 & 0,013 & 0,008 & 0,004 & 0,022 & 0,009 & 0,006 \\
\hline Shopee & 0,065 & 0,043 & 0,136 & 0,042 & 0,270 & 0,159 & 0,389 & 0,119 & 0,263 & 0,288 & 0,071 \\
\hline Bukalapak & 0,043 & 0,085 & 0,068 & 0,021 & 0,017 & 0,004 & 0,006 & 0,007 & 0,007 & 0,004 & 0,018 \\
\hline Blibli & 0,033 & 0,128 & 0,034 & 0,042 & 0,067 & 0,053 & 0,194 & 0,179 & 0,351 & 0,144 & 0,213 \\
\hline Zalora & 0,130 & 0,170 & 0,023 & 0,085 & 0,034 & 0,027 & 0,012 & 0,005 & 0,005 & 0,009 & 0,006 \\
\hline Hijup & 0,065 & 0,085 & 0,017 & 0,127 & 0,017 & 0,053 & 0,049 & 0,060 & 0,176 & 0,216 & 0,284 \\
\hline JD.id & 0,043 & 0,128 & 0,034 & 0,170 & 0,011 & 0,106 & 0,024 & 0,030 & 0,011 & 0,006 & 0,004 \\
\hline Elevenia & 0,033 & 0,170 & 0,023 & 0,085 & 0,008 & 0,159 & 0,012 & 0,060 & 0,044 & 0,072 & 0,142 \\
\hline Bhinneka & 0,130 & 0,043 & 0,017 & 0,127 & 0,017 & 0,212 & 0,008 & 0,119 & 0,022 & 0,036 & 0,009 \\
\hline Qooi10 & & & & & & & & & & & \\
Indonesia & 0,065 & 0,085 & 0,068 & 0,170 & 0,011 & 0,106 & 0,006 & 0,179 & 0,011 & 0,072 & 0,035 \\
\hline
\end{tabular}

Tabel 4e. Sosial Media Link

\begin{tabular}{|c|c|c|c|c|c|c|c|c|c|c|c|}
\hline & Lazada & Tokopedia & Shopee & Bukalapak & Blibli & Zalora & Hijup & JD.id & Elevenia & Bhinneka & $\begin{array}{c}\text { Qoo10 } \\
\text { Indonesia }\end{array}$ \\
\hline Lazada & 0,286 & 0,113 & 0,552 & 0,048 & 0,529 & 0,145 & 0,212 & 0,068 & 0,299 & 0,202 & 0,131 \\
\hline Tokopedia & 0,048 & 0,019 & 0,023 & 0,006 & 0,033 & 0,003 & 0,009 & 0,008 & 0,019 & 0,004 & 0,005 \\
\hline Shopee & 0,071 & 0,113 & 0,138 & 0,145 & 0,264 & 0,048 & 0,424 & 0,203 & 0,150 & 0,067 & 0,262 \\
\hline Bukalapak & 0,143 & 0,075 & 0,023 & 0,024 & 0,011 & 0,006 & 0,026 & 0,004 & 0,006 & 0,008 & 0,016 \\
\hline Blibli & 0,036 & 0,038 & 0,034 & 0,145 & 0,066 & 0,145 & 0,212 & 0,068 & 0,299 & 0,202 & 0,131 \\
\hline Zalora & 0,048 & 0,151 & 0,069 & 0,097 & 0,011 & 0,024 & 0,009 & 0,008 & 0,019 & 0,004 & 0,005 \\
\hline Hijup & 0,071 & 0,113 & 0,017 & 0,048 & 0,017 & 0,145 & 0,053 & 0,203 & 0,150 & 0,067 & 0,262 \\
\hline JD.id & 0,143 & 0,075 & 0,023 & 0,194 & 0,033 & 0,097 & 0,009 & 0,034 & 0,006 & 0,008 & 0,016 \\
\hline Elevenia & 0,036 & 0,038 & 0,034 & 0,145 & 0,008 & 0,048 & 0,013 & 0,203 & 0,037 & 0,202 & 0,131 \\
\hline Bhinneka & 0,048 & 0,151 & 0,069 & 0,097 & 0,011 & 0,193 & 0,026 & 0,135 & 0,006 & 0,034 & 0,005 \\
\hline $\begin{array}{l}\text { Qoo10 } \\
\text { Indonesia }\end{array}$ & 0,071 & 0,113 & 0,017 & 0,048 & 0,017 & 0,145 & 0,007 & 0,068 & 0,009 & 0,202 & 0,033 \\
\hline
\end{tabular}

Setelah dilakukan proses pembagian kemudian dilakukan proses penjumlahan dan membuat rata-rata setiap baris pada setiap alternatif yang dapat dilihat pada tabel 5a sampai dengan 5 i.

Tabel 5a. Logo yang Jelas

\begin{tabular}{|c|c|c|c|c|c|c|c|c|c|c|c|c|c|}
\hline & Lazada & Tokopedia & Shopee & Bukalapak & Blibli & Zalora & Hijup & JD.id & Elevenia & Bhinneka & $\begin{array}{c}\text { Qoo10 } \\
\text { Indonesia }\end{array}$ & Jml & $\begin{array}{l}\text { Rata- } \\
\text { rata }\end{array}$ \\
\hline Lazada & 0,261 & 0,044 & 0,527 & 0,145 & 0,518 & 0,060 & 0,208 & 0,201 & 0,295 & 0,092 & 0,130 & 2,482 & 0,226 \\
\hline Tokopedia & 0,130 & 0,022 & 0,066 & 0,006 & 0,011 & 0,004 & 0,026 & 0,008 & 0,006 & 0,006 & 0,016 & 0,302 & 0,027 \\
\hline Shopee & 0,065 & 0,044 & 0,132 & 0,048 & 0,259 & 0,180 & 0,416 & 0,067 & 0,148 & 0,276 & 0,259 & 1,895 & 0,172 \\
\hline Bukalapak & 0,043 & 0,089 & 0,066 & 0,024 & 0,032 & 0,007 & 0,009 & 0,004 & 0,018 & 0,011 & 0,005 & 0,311 & 0,028 \\
\hline Blibli & 0,033 & 0,133 & 0,033 & 0,048 & 0,065 & 0,060 & 0,208 & 0,201 & 0,295 & 0,092 & 0,130 & 1,298 & 0,118 \\
\hline Zalora & 0,130 & 0,178 & 0,022 & 0,097 & 0,032 & 0,030 & 0,026 & 0,017 & 0,006 & 0,006 & 0,016 & 0,560 & 0,051 \\
\hline Hijup & 0,065 & 0,044 & 0,016 & 0,145 & 0,016 & 0,060 & 0,052 & 0,067 & 0,148 & 0,276 & 0,259 & 1,150 & 0,105 \\
\hline JD.id & 0,043 & 0,089 & 0,066 & 0,194 & 0,011 & 0,120 & 0,026 & 0,033 & 0,018 & 0,011 & 0,005 & 0,618 & 0,056 \\
\hline Elevenia & 0,033 & 0,133 & 0,033 & 0,048 & 0,008 & 0,180 & 0,013 & 0,067 & 0,037 & 0,092 & 0,130 & 0,774 & 0,070 \\
\hline Bhinneka & 0,130 & 0,178 & 0,022 & 0,097 & 0,032 & 0,240 & 0,009 & 0,134 & 0,018 & 0,046 & 0,016 & 0,922 & 0,084 \\
\hline \multirow[t]{2}{*}{$\begin{array}{l}\text { Qoo10 } \\
\text { Indonesia }\end{array}$} & 0,065 & 0,044 & 0,016 & 0,145 & 0,016 & 0,060 & 0,007 & 0,201 & 0,009 & 0,092 & 0,032 & 0,689 & 0,063 \\
\hline & & & & & & & & & & & & Jml & 1,000 \\
\hline
\end{tabular}

Pada tabel 5a nilai jumlah pada baris lazada didapat dari penjumlahan seluruh nilai pada baris lazada yaitu $2,482=0,261+0,044+0,527+0,145+0,518+0,060+0,208+0,201+0,295+0,092+0,130$ Kemudian dilakukan proses rata-rata $=2,482 / 12=0,266$. Proses ini berlaku sama untuk semua nilai di tabel 5 b sampai dengan 5 i. 
Tabel 5b. Penawaran Khusus

\begin{tabular}{|c|c|c|c|c|c|c|c|c|c|c|c|c|c|}
\hline & Lazada & Tokopedia & Shopee & Bukalapak & Blibli & Zalora & Hijup & JD.id & Elevenia & Bhinneka & $\begin{array}{c}\text { Qoo10 } \\
\text { Indonesia }\end{array}$ & $\mathbf{J m l}$ & $\begin{array}{c}\text { Rata- } \\
\text { rata }\end{array}$ \\
\hline Lazada & 0,286 & 0,082 & 0,643 & 0,156 & 0,185 & 0,096 & 0,360 & 0,183 & 0,110 & 0,117 & 0,250 & 2,466 & 0,224 \\
\hline Tokopedia & 0,071 & 0,020 & 0,027 & 0,003 & 0,012 & 0,012 & 0,015 & 0,004 & 0,007 & 0,015 & 0,010 & 0,196 & 0,018 \\
\hline Shopee & 0,048 & 0,082 & 0,107 & 0,078 & 0,554 & 0,192 & 0,120 & 0,091 & 0,330 & 0,233 & 0,083 & 1,918 & 0,174 \\
\hline Bukalapak & 0,036 & 0,122 & 0,027 & 0,020 & 0,023 & 0,004 & 0,008 & 0,011 & 0,014 & 0,005 & 0,005 & 0,274 & 0,025 \\
\hline Blibli & 0,143 & 0,163 & 0,018 & 0,078 & 0,092 & 0,096 & 0,360 & 0,183 & 0,110 & 0,117 & 0,250 & 1,610 & 0,146 \\
\hline Zalora & 0,071 & 0,041 & 0,013 & 0,117 & 0,023 & 0,024 & 0,015 & 0,004 & 0,007 & 0,015 & 0,010 & 0,341 & 0,031 \\
\hline Hijup & 0,048 & 0,082 & 0,054 & 0,156 & 0,015 & 0,096 & 0,060 & 0,091 & 0,330 & 0,233 & 0,083 & 1,248 & 0,113 \\
\hline JD.id & 0,036 & 0,122 & 0,027 & 0,039 & 0,012 & 0,144 & 0,015 & 0,023 & 0,014 & 0,005 & 0,005 & 0,441 & 0,040 \\
\hline Elevenia & 0,143 & 0,163 & 0,018 & 0,078 & 0,046 & 0,192 & 0,010 & 0,091 & 0,055 & 0,117 & 0,250 & 1,163 & 0,106 \\
\hline Bhinneka & 0,071 & 0,041 & 0,013 & 0,117 & 0,023 & 0,048 & 0,008 & 0,137 & 0,014 & 0,029 & 0,010 & 0,512 & 0,047 \\
\hline $\begin{array}{l}\text { Qoo10 } \\
\text { Indonesia }\end{array}$ & 0,048 & 0,082 & 0,054 & 0,156 & 0,015 & 0,096 & 0,030 & 0,183 & 0,009 & 0,117 & 0,042 & 0,830 & 0,075 \\
\hline
\end{tabular}

Tabel 5c. Pengiriman Gratis

\begin{tabular}{|c|c|c|c|c|c|c|c|c|c|c|c|c|c|}
\hline & Lazada & Tokopedia & Shopee & Bukalapak & Blibli & Zalora & Hijup & JD.id & Elevenia & Bhinneka & $\begin{array}{c}\text { Qoo10 } \\
\text { Indonesia }\end{array}$ & Jml & $\begin{array}{c}\text { Rata- } \\
\text { rata }\end{array}$ \\
\hline Lazada & 0,018 & 0,051 & 0,002 & 0,045 & 0,006 & 0,011 & 0,004 & 0,007 & 0,004 & 0,014 & 0,009 & 0,169 & 0,015 \\
\hline Tokopedia & 0,105 & 0,304 & 0,109 & 0,716 & 0,046 & 0,266 & 0,169 & 0,351 & 0,168 & 0,219 & 0,111 & 2,565 & 0,233 \\
\hline Shopee & 0,140 & 0,051 & 0,018 & 0,015 & 0,003 & 0,033 & 0,007 & 0,007 & 0,004 & 0,005 & 0,007 & 0,290 & 0,026 \\
\hline Bukalapak & 0,035 & 0,038 & 0,109 & 0,090 & 0,138 & 0,532 & 0,056 & 0,176 & 0,168 & 0,219 & 0,334 & 1,895 & 0,172 \\
\hline Blibli & 0,070 & 0,152 & 0,145 & 0,015 & 0,023 & 0,011 & 0,004 & 0,022 & 0,007 & 0,005 & 0,007 & 0,460 & 0,042 \\
\hline Zalora & 0,105 & 0,076 & 0,036 & 0,011 & 0,138 & 0,066 & 0,169 & 0,351 & 0,056 & 0,110 & 0,334 & 1,453 & 0,132 \\
\hline Hijup & 0,140 & 0,051 & 0,073 & 0,045 & 0,184 & 0,011 & 0,028 & 0,007 & 0,004 & 0,014 & 0,014 & 0,570 & 0,052 \\
\hline JD.id & 0,105 & 0,038 & 0,109 & 0,022 & 0,046 & 0,008 & 0,169 & 0,044 & 0,168 & 0,219 & 0,111 & 1,041 & 0,095 \\
\hline Elevenia & 0,140 & 0,051 & 0,145 & 0,015 & 0,092 & 0,033 & 0,225 & 0,007 & 0,028 & 0,005 & 0,007 & 0,749 & 0,068 \\
\hline Bhinneka & 0,035 & 0,038 & 0,109 & 0,011 & 0,138 & 0,017 & 0,056 & 0,005 & 0,168 & 0,027 & 0,009 & 0,615 & 0,056 \\
\hline $\begin{array}{l}\text { Qoo10 } \\
\text { Indonesia }\end{array}$ & 0,105 & 0,152 & 0,145 & 0,015 & 0,184 & 0,011 & 0,113 & 0,022 & 0,225 & 0,164 & 0,056 & 1,192 & 0,108 \\
\hline
\end{tabular}

Tabel 5d. Berita Terbaru

\begin{tabular}{lcccccccccccccc}
\hline & Lazada & Tokopedia & Shopee & Bukalapak & Blibli & Zalora & Hijup & JD.id & Elevenia & Bhinneka & $\begin{array}{c}\text { Qoo10 } \\
\text { Indonesia }\end{array}$ & $\begin{array}{c}\text { Jml } \\
\text { Rata- } \\
\text { rata }\end{array}$ \\
\hline Lazada & 0,020 & 0,038 & 0,010 & 0,047 & 0,004 & 0,012 & 0,012 & 0,020 & 0,005 & 0,005 & 0,019 & 0,190 & 0,017 \\
\hline Tokopedia & 0,157 & 0,300 & 0,162 & 0,378 & 0,092 & 0,563 & 0,190 & 0,158 & 0,110 & 0,232 & 0,297 & 2,637 & 0,240 \\
\hline Shopee & 0,039 & 0,038 & 0,020 & 0,024 & 0,011 & 0,023 & 0,004 & 0,010 & 0,014 & 0,010 & 0,006 & 0,199 & 0,018 \\
\hline Bukalapak & 0,078 & 0,150 & 0,162 & 0,189 & 0,183 & 0,188 & 0,095 & 0,475 & 0,220 & 0,077 & 0,148 & 1,966 & 0,179 \\
\hline Blibli & 0,118 & 0,075 & 0,040 & 0,024 & 0,023 & 0,012 & 0,012 & 0,020 & 0,005 & 0,005 & 0,019 & 0,351 & 0,032 \\
\hline Zalora & 0,157 & 0,050 & 0,081 & 0,094 & 0,183 & 0,094 & 0,190 & 0,158 & 0,110 & 0,232 & 0,297 & 1,646 & 0,150 \\
\hline Hijup & 0,039 & 0,038 & 0,121 & 0,047 & 0,046 & 0,012 & 0,024 & 0,010 & 0,014 & 0,010 & 0,006 & 0,366 & 0,033 \\
\hline JD.id & 0,078 & 0,150 & 0,162 & 0,031 & 0,092 & 0,047 & 0,190 & 0,079 & 0,220 & 0,077 & 0,148 & 1,275 & 0,116 \\
\hline Elevenia & 0,118 & 0,075 & 0,040 & 0,024 & 0,137 & 0,023 & 0,047 & 0,010 & 0,028 & 0,005 & 0,019 & 0,526 & 0,048 \\
\hline Bhinneka & 0,157 & 0,050 & 0,081 & 0,094 & 0,183 & 0,016 & 0,095 & 0,040 & 0,220 & 0,039 & 0,005 & 0,979 & 0,089 \\
\hline $\begin{array}{l}\text { Qool0 } \\
\text { Indonesia }\end{array}$ & 0,039 & 0,038 & 0,121 & 0,047 & 0,046 & 0,012 & 0,142 & 0,020 & 0,055 & 0,309 & 0,037 & 0,866 & 0,079 \\
\hline & & & & & & & & & & & & Jml & 1,000 \\
\hline
\end{tabular}

Tabel 5e. Toko Finder

\begin{tabular}{lccccccccccccc}
\hline & Lazada & Tokopedia & Shopee & Bukalapak & Blibli & Zalora & Hijup & JD.id & Elevenia & Bhinneka & $\begin{array}{c}\text { Qoo10 } \\
\text { Indonesia }\end{array}$ & $\begin{array}{c}\text { Jml } \\
\text { Rata- } \\
\text { rata }\end{array}$ \\
\hline Lazada & 0,020 & 0,038 & 0,010 & 0,047 & 0,004 & 0,012 & 0,012 & 0,020 & 0,005 & 0,005 & 0,019 & 0,190 & 0,017 \\
\hline Tokopedia & 0,157 & 0,300 & 0,162 & 0,378 & 0,092 & 0,563 & 0,190 & 0,158 & 0,110 & 0,232 & 0,297 & 2,637 & 0,240 \\
\hline Shopee & 0,039 & 0,038 & 0,020 & 0,024 & 0,011 & 0,023 & 0,004 & 0,010 & 0,014 & 0,010 & 0,006 & 0,199 & 0,018 \\
\hline Bukalapak & 0,078 & 0,150 & 0,162 & 0,189 & 0,183 & 0,188 & 0,095 & 0,475 & 0,220 & 0,077 & 0,148 & 1,966 & 0,179 \\
\hline Blibli & 0,118 & 0,075 & 0,040 & 0,024 & 0,023 & 0,012 & 0,012 & 0,020 & 0,005 & 0,005 & 0,019 & 0,351 & 0,032 \\
\hline Zalora & 0,157 & 0,050 & 0,081 & 0,094 & 0,183 & 0,094 & 0,190 & 0,158 & 0,110 & 0,232 & 0,297 & 1,646 & 0,150 \\
\hline Hijup & 0,039 & 0,038 & 0,121 & 0,047 & 0,046 & 0,012 & 0,024 & 0,010 & 0,014 & 0,010 & 0,006 & 0,366 & 0,033 \\
\hline JD.id & 0,078 & 0,150 & 0,162 & 0,031 & 0,092 & 0,047 & 0,190 & 0,079 & 0,220 & 0,077 & 0,148 & 1,275 & 0,116 \\
\hline Elevenia & 0,118 & 0,075 & 0,040 & 0,024 & 0,137 & 0,023 & 0,047 & 0,010 & 0,028 & 0,005 & 0,019 & 0,526 & 0,048 \\
\hline Bhinneka & 0,157 & 0,050 & 0,081 & 0,094 & 0,183 & 0,016 & 0,095 & 0,040 & 0,220 & 0,039 & 0,005 & 0,979 & 0,089 \\
\hline $\begin{array}{l}\text { Qoo10 } \\
\text { Indonesia }\end{array}$ & 0,039 & 0,038 & 0,121 & 0,047 & 0,046 & 0,012 & 0,142 & 0,020 & 0,055 & 0,309 & 0,037 & 0,866 & 0,079 \\
\hline & & & & & & & & & & & & & \\
\hline
\end{tabular}


Dari tabel 5a sampai dengan 5i akan membentuk matriks preferensi yang disajikan pada tabel 6 Dibawah ini.

Tabel 6. Matrik Preferensi Alternatif terhadap Kriteria

\begin{tabular}{|c|c|c|c|c|c|c|c|c|c|c|c|c|}
\hline \multirow[b]{2}{*}{ Alternatif } & \multicolumn{12}{|c|}{ KRITERIA } \\
\hline & $\begin{array}{l}\text { Logo } \\
\text { yang } \\
\text { Jelas }\end{array}$ & $\begin{array}{c}\text { Penawaran } \\
\text { Khusus }\end{array}$ & $\begin{array}{l}\text { Pengiriman } \\
\text { Gratis }\end{array}$ & $\begin{array}{l}\text { Berita } \\
\text { terbaru }\end{array}$ & $\begin{array}{l}\text { Produk } \\
\text { Popular }\end{array}$ & $\begin{array}{l}\text { Merk } \\
\text { Produk }\end{array}$ & $\begin{array}{l}\text { Penempatan } \\
\text { Shopping } \\
\text { Cart, Login } \\
\text { Box dan } \\
\text { Search Box }\end{array}$ & $\begin{array}{c}\text { Pemba } \\
\text { yaran } \\
\text { Sistem } \\
\text { Icon }\end{array}$ & $\begin{array}{c}\text { Sosial } \\
\text { Media } \\
\text { Link }\end{array}$ & $\begin{array}{c}\text { Nomor } \\
\text { telefon } \\
\text { dan } \\
\text { Chating } \\
\text { Online }\end{array}$ & $\begin{array}{l}\text { Toko } \\
\text { Finder }\end{array}$ & $\begin{array}{l}\text { Trust } \\
\text { mark }\end{array}$ \\
\hline Lazada & 0,226 & 0,224 & 0,015 & 0,017 & 0,224 & 0,236 & 0,226 & 0,019 & 0,235 & 0,015 & 0,017 & 0,019 \\
\hline Tokopedia & 0,027 & 0,018 & 0,233 & 0,240 & 0,018 & 0,024 & 0,027 & 0,240 & 0,016 & 0,233 & 0,240 & 0,240 \\
\hline Shopee & 0,172 & 0,174 & 0,026 & 0,018 & 0,174 & 0,168 & 0,172 & 0,023 & 0,171 & 0,026 & 0,018 & 0,023 \\
\hline Bukalapak & 0,028 & 0,025 & 0,172 & 0,179 & 0,025 & 0,026 & 0,028 & 0,155 & 0,031 & 0,172 & 0,179 & 0,045 \\
\hline Blibli & 0,118 & 0,146 & 0,042 & 0,032 & 0,146 & 0,131 & 0,118 & 0,045 & 0,125 & 0,042 & 0,032 & 0,045 \\
\hline Zalora & 0,051 & 0,031 & 0,132 & 0,150 & 0,031 & 0,046 & 0,051 & 0,131 & 0,040 & 0,132 & 0,150 & 0,131 \\
\hline Hijup & 0,105 & 0,113 & 0,052 & 0,033 & 0,113 & 0,104 & 0,105 & 0,049 & 0,104 & 0,052 & 0,033 & 0,049 \\
\hline JD.id & 0,056 & 0,040 & 0,095 & 0,116 & 0,040 & 0,052 & 0,056 & 0,090 & 0,058 & 0,095 & 0,116 & 0,090 \\
\hline Elevenia & 0,070 & 0,106 & 0,068 & 0,048 & 0,106 & 0,073 & 0,070 & 0,075 & 0,081 & 0,068 & 0,048 & 0,075 \\
\hline Bhinneka & 0,084 & 0,047 & 0,056 & 0,089 & 0,047 & 0,067 & 0,084 & 0,088 & 0,071 & 0,056 & 0,089 & 0,088 \\
\hline $\begin{array}{l}\text { Qoo10 } \\
\text { Indonesia }\end{array}$ & 0,063 & 0,075 & 0,108 & 0,079 & 0,075 & 0,074 & 0,063 & 0,083 & 0,066 & 0,108 & 0,079 & 0,083 \\
\hline
\end{tabular}

Selanjutnya melakukan pembentukan matriks perbandingan berpasangan pada kriteria yang disajikan pada tabel 7. Setiap kriteria diisi dengan nilai sesuai pada tabel 1.

Tabel 7. Matriks Perbandingan Berpasangan pada Kriteria

\begin{tabular}{|c|c|c|c|c|c|c|c|c|c|c|c|c|}
\hline KRITERIA & $\begin{array}{l}\text { Logo } \\
\text { yang } \\
\text { Jelas }\end{array}$ & $\begin{array}{l}\text { Penawa } \\
\text { ran } \\
\text { Khusus }\end{array}$ & $\begin{array}{c}\text { Pengiriman } \\
\text { Gratis }\end{array}$ & $\begin{array}{l}\text { Berita } \\
\text { terbaru }\end{array}$ & $\begin{array}{l}\text { Produk } \\
\text { Popular }\end{array}$ & $\begin{array}{l}\text { Merk } \\
\text { Produk }\end{array}$ & $\begin{array}{l}\text { Penempatan } \\
\text { Shopping } \\
\text { Cart, Login } \\
\text { Box dan } \\
\text { Search Box }\end{array}$ & $\begin{array}{l}\text { Pemba } \\
\text { yaran } \\
\text { Sistem } \\
\text { Icon }\end{array}$ & $\begin{array}{l}\text { Sosial } \\
\text { Media } \\
\text { Link }\end{array}$ & $\begin{array}{c}\text { Nomor } \\
\text { telefon } \\
\text { dan } \\
\text { Chating } \\
\text { Online }\end{array}$ & $\begin{array}{l}\text { Toko } \\
\text { Finder }\end{array}$ & $\begin{array}{l}\text { Trust } \\
\text { mark }\end{array}$ \\
\hline Logo yang Jelas & 1 & 0,500 & 0,333 & 0,200 & 0,500 & 0,333 & 0,500 & 0,333 & 0,500 & 0,333 & 0,500 & 0,333 \\
\hline Penawaran Khusus & 2 & 1 & 2 & 5 & 2 & 9 & 2 & 6 & 8 & 2 & 3 & 2 \\
\hline Pengiriman Gratis & 3 & 0,500 & 1 & 0,333 & 0,500 & 0,250 & 0,167 & 0,143 & 0,500 & 0,200 & 0,167 & 0,125 \\
\hline Berita terbaru & 5 & 0,200 & 3 & 1 & 3 & 7 & 9 & 7 & 3 & 9 & 6 & 3 \\
\hline Produk Popular & 2 & 0,500 & 2 & 0,333 & 1 & 0,333 & 0,143 & 0,200 & 0,500 & 0,111 & 0,200 & 0,333 \\
\hline Merk Produk & 3 & 0,111 & 4 & 0,143 & 3 & 1 & 5 & 9 & 2 & 9 & 9 & 9 \\
\hline $\begin{array}{l}\text { Penempatan } \\
\text { Shopping Cart, } \\
\text { Login Box dan } \\
\text { Search Box }\end{array}$ & 2 & 0,500 & 6 & 0,111 & 7 & 0,200 & 1 & 0,111 & 0,143 & 0,250 & 0,125 & 0,200 \\
\hline $\begin{array}{l}\text { Pembayaran Sistem } \\
\text { Icon }\end{array}$ & 3 & 0,167 & 7 & 0,143 & 5 & 0,111 & 9 & 1 & 3 & 7 & 9 & 7 \\
\hline Sosial Media Link & 2 & 0,125 & 2 & 0,333 & 2 & 0,500 & 7 & 0,333 & 1 & 0,111 & 0,111 & 0,143 \\
\hline $\begin{array}{l}\text { Nomor telefon dan } \\
\text { Chating Online }\end{array}$ & 3 & 0,500 & 5 & 0,111 & 9 & 0,111 & 4 & 0,143 & 9 & 1 & 7 & 5 \\
\hline Toko Finder & 2 & 0,333 & 6 & 0,167 & 5 & 0,111 & 8 & 0,111 & 9 & 0,143 & 1 & 0,500 \\
\hline Trustmark & 3 & 0,167 & 8 & 0,333 & 3 & 0,111 & 5 & 0,143 & 7 & 0,200 & 2 & 1 \\
\hline JUMLAH & 31 & 5 & 46 & 8 & 41 & 19 & 51 & 25 & 44 & 29 & 38 & 29 \\
\hline
\end{tabular}

Kemudian dilakukan normalisasi matrik seperti pada tabel 8 dibawah ini :

Tabel 8. Normalisasi Matriks

\begin{tabular}{|c|c|c|c|c|c|c|c|c|c|c|c|c|c|}
\hline KRITERIA & $\begin{array}{l}\text { Logo } \\
\text { yang } \\
\text { Jelas }\end{array}$ & $\begin{array}{c}\text { Pena } \\
\text { waran } \\
\text { Khus } \\
\text { us }\end{array}$ & $\begin{array}{c}\text { Pengiri } \\
\text { man } \\
\text { Gratis }\end{array}$ & $\begin{array}{l}\text { Berita } \\
\text { terbaru }\end{array}$ & $\begin{array}{l}\text { Produk } \\
\text { Popular }\end{array}$ & $\begin{array}{l}\text { Merk } \\
\text { Produk }\end{array}$ & $\begin{array}{l}\text { Penempatan } \\
\text { Shopping } \\
\text { Cart, Login } \\
\text { Box dan } \\
\text { Search Box }\end{array}$ & $\begin{array}{l}\text { Pembayaran } \\
\text { Sistem Icon }\end{array}$ & $\begin{array}{l}\text { Sosial } \\
\text { Media } \\
\text { Link }\end{array}$ & $\begin{array}{l}\text { Nomor } \\
\text { telefon dan } \\
\text { Chating } \\
\text { Online }\end{array}$ & $\begin{array}{l}\text { Toko } \\
\text { Finder }\end{array}$ & Trustmark & $\begin{array}{c}\text { Rata- } \\
\text { rata }\end{array}$ \\
\hline Logo yang Jelas & 0,032 & 0,109 & 0,007 & 0,024 & 0,012 & 0,017 & 0,010 & 0,014 & 0,011 & 0,011 & 0,013 & 0,012 & 0,023 \\
\hline $\begin{array}{l}\text { Penawaran } \\
\text { Khusus }\end{array}$ & 0,065 & 0,217 & 0,043 & 0,609 & 0,049 & 0,472 & 0,039 & 0,245 & 0,183 & 0,068 & 0,079 & 0,070 & 0,178 \\
\hline $\begin{array}{l}\text { Pengiriman } \\
\text { Gratis }\end{array}$ & 0,097 & 0,109 & 0,022 & 0,041 & 0,012 & 0,013 & 0,003 & 0,006 & 0,011 & 0,007 & 0,004 & 0,004 & 0,027 \\
\hline Berita terbaru & 0,161 & 0,043 & 0,065 & 0,122 & 0,073 & 0,367 & 0,177 & 0,286 & 0,069 & 0,307 & 0,157 & 0,105 & 0,161 \\
\hline Produk Popular & 0,065 & 0,109 & 0,043 & 0,041 & 0,024 & 0,017 & 0,003 & 0,008 & 0,011 & 0,004 & 0,005 & 0,012 & 0,028 \\
\hline Merk Produk & 0,097 & 0,024 & 0,086 & 0,017 & 0,073 & 0,052 & 0,098 & 0,367 & 0,046 & 0,307 & 0,236 & 0,314 & 0,143 \\
\hline $\begin{array}{l}\text { Penempatan } \\
\text { Shopping Cart, } \\
\text { Login Box dan }\end{array}$ & 0,065 & 0,109 & 0,129 & 0,014 & 0,171 & 0,010 & 0,020 & 0,005 & 0,003 & 0,009 & 0,003 & 0,007 & 0,045 \\
\hline
\end{tabular}


Search Box

\begin{tabular}{|c|c|c|c|c|c|c|c|c|c|c|c|c|c|}
\hline $\begin{array}{l}\text { Pembayaran } \\
\text { Sistem Icon }\end{array}$ & 0,097 & 0,036 & 0,151 & 0,017 & 0,122 & 0,006 & 0,177 & 0,041 & 0,069 & 0,239 & 0,236 & 0,244 & 0,120 \\
\hline $\begin{array}{l}\text { Sosial Media } \\
\text { Link }\end{array}$ & 0,065 & 0,027 & 0,043 & 0,041 & 0,049 & 0,026 & 0,138 & 0,014 & 0,023 & 0,004 & 0,003 & 0,005 & 0,036 \\
\hline $\begin{array}{l}\text { Nomor telefon } \\
\text { dan Chating } \\
\text { Online }\end{array}$ & 0,097 & 0,109 & 0,108 & 0,014 & 0,220 & 0,006 & 0,079 & 0,006 & 0,206 & 0,034 & 0,184 & 0,175 & 0,103 \\
\hline Toko Finder & 0,065 & 0,072 & 0,129 & 0,020 & 0,122 & 0,006 & 0,157 & 0,005 & 0,206 & 0,005 & 0,026 & 0,017 & 0,069 \\
\hline \multirow[t]{2}{*}{ Trustmark } & 0,097 & 0,036 & 0,173 & 0,041 & 0,073 & 0,006 & 0,098 & 0,006 & 0,160 & 0,007 & 0,052 & 0,035 & 0,065 \\
\hline & & & & & & & & & & & & JUMLAH & 1,000 \\
\hline
\end{tabular}

Setelah didapatkan normalisasi matriks maka dilakukan perkalian antara nilai pada tabel 6 dengan nilai ratarata pada tabel 8 untuk mendapatkan vektor preferensi. Hasilnya ditabulasikan pada tabel 9.

Tabel 9. Vektor Preferensi

\begin{tabular}{|c|c|c|c|c|c|c|c|c|c|c|c|c|c|}
\hline & Lazada & Tokopedia & Shopee & Bukalapak & Blibli & Zalora & Hijup & JD.id & Elevenia & Bhinneka & $\begin{array}{c}\text { Qoo10 } \\
\text { Indonesia }\end{array}$ & JUMLAH & $\begin{array}{c}\text { VEKTOR } \\
\text { PREFERENSI }\end{array}$ \\
\hline $\begin{array}{l}\text { Logo yang } \\
\text { Jelas }\end{array}$ & 0,023 & 0,089 & 0,009 & 0,032 & 0,014 & 0,048 & 0,023 & 0,040 & 0,018 & 0,035 & 0,022 & 0,352 & 15,4793 \\
\hline $\begin{array}{l}\text { Penawaran } \\
\text { Khusus }\end{array}$ & 0,357 & 0,027 & 0,322 & 0,142 & 0,286 & 0,408 & 0,239 & 0,218 & 0,824 & 0,196 & 0,000 & 3,020 & 16,9391 \\
\hline $\begin{array}{l}\text { Pengiriman } \\
\text { Gratis }\end{array}$ & 0,082 & 0,081 & 0,028 & 0,048 & 0,023 & 0,030 & 0,006 & 0,015 & 0,035 & 0,000 & 0,000 & 0,347 & 12,6537 \\
\hline $\begin{array}{l}\text { Berita } \\
\text { terbaru }\end{array}$ & 0,805 & 0,006 & 0,430 & 0,045 & 0,359 & 0,255 & 0,927 & 0,485 & 0,196 & 0,000 & 0,000 & 3,507 & 21,7796 \\
\hline $\begin{array}{l}\text { Produk } \\
\text { Popular }\end{array}$ & 0,057 & 0,072 & 0,091 & 0,040 & 0,036 & 0,034 & 0,010 & 0,013 & 0,000 & 0,000 & 0,000 & 0,353 & 12,3799 \\
\hline $\begin{array}{l}\text { Merk } \\
\text { Produk }\end{array}$ & 0,430 & 0,005 & 0,478 & 0,005 & 0,309 & 0,069 & 0,327 & 0,000 & 0,000 & 0,000 & 0,000 & 1,623 & 11,3321 \\
\hline $\begin{array}{l}\text { Penempatan } \\
\text { Shopping } \\
\text { Cart, Login } \\
\text { Box dan } \\
\text { Search Box } \\
\end{array}$ & 0,091 & 0,060 & 0,218 & 0,011 & 0,485 & 0,013 & 0,000 & 0,000 & 0,000 & 0,000 & 0,000 & 0,878 & 19,3804 \\
\hline $\begin{array}{l}\text { Pembayaran } \\
\text { Sistem Icon }\end{array}$ & 0,359 & 0,006 & 0,721 & 0,010 & 0,327 & 0,000 & 0,000 & 0,000 & 0,000 & 0,000 & 0,000 & 1,422 & 11,8912 \\
\hline $\begin{array}{l}\text { Sosial } \\
\text { Media Link }\end{array}$ & 0,073 & 0,013 & 0,139 & 0,022 & 0,000 & 0,000 & 0,000 & 0,000 & 0,000 & 0,000 & 0,000 & 0,246 & 6,76221 \\
\hline $\begin{array}{l}\text { Nomor } \\
\text { telefon dan } \\
\text { Chating } \\
\text { Online }\end{array}$ & 0,309 & 0,035 & 0,327 & 0,000 & 0,000 & 0,000 & 0,000 & 0,000 & 0,000 & 0,000 & 0,000 & 0,670 & 6,51004 \\
\hline $\begin{array}{l}\text { Toko } \\
\text { Finder }\end{array}$ & 0,139 & 0,022 & 0,000 & 0,000 & 0,000 & 0,000 & 0,000 & 0,000 & 0,000 & 0,000 & 0,000 & 0,160 & 2,31441 \\
\hline Trustmark & 0,196 & 0,000 & 0,000 & 0,000 & 0,000 & 0,000 & 0,000 & 0,000 & 0,000 & 0,000 & 0,000 & 0,196 & 3 \\
\hline & & & & & & & & & & & & $\sum \lambda$ & 140,422 \\
\hline
\end{tabular}

\section{Prinsip Konsistensi}

Dari tabel dapat dihitung nilai lamda $(\lambda) \max , C I$ dan $C R$ dengan rumus pada persamaan (1), (2), dan (3) yang hasilnya adalah :
(1) $\lambda \max =\sum \lambda / \mathrm{n}=140,422 / 12=11,702$
(2) $\mathrm{CI}=(\lambda \max -\mathrm{n}) /(\mathrm{n}-1)$

$$
=(11,702-12) /(12-1)=0,298 / 11=-0,027
$$

(3) $\mathrm{CR}=\mathrm{CI} / \mathrm{IRC}=-0,027 / 1,48$

$\mathrm{CR}=-0,018$ atau $-2 \%$

Karena $\mathrm{CR}<=0,1$ maka nilai perbandingan berpasangan pada matriks kriteria yang diberikan konsisten dan hasil analisis AHP ampuh dalam pengambilan keputusan.

Tahapan terakhir yaitu proses penentuan perangkingan alternatif seperti tabel 10 .

Tabel 10. Perangkingan alternatif

\begin{tabular}{|c|c|c|c|c|c|c|c|c|c|c|c|c|c|}
\hline & $\begin{array}{l}\text { Logo } \\
\text { yang } \\
\text { Jelas }\end{array}$ & $\begin{array}{l}\text { Penawa } \\
\text { ran } \\
\text { Khusus }\end{array}$ & $\begin{array}{c}\text { Pengiriman } \\
\text { Gratis }\end{array}$ & $\begin{array}{c}\text { Berita } \\
\text { terbaru }\end{array}$ & $\begin{array}{l}\text { Produk } \\
\text { Popular }\end{array}$ & $\begin{array}{c}\text { Merk } \\
\text { Produk }\end{array}$ & $\begin{array}{l}\text { Penempatan } \\
\text { Shopping } \\
\text { Cart, Login } \\
\text { Box dan } \\
\text { Search Box }\end{array}$ & $\begin{array}{l}\text { Pembayar } \\
\text { an Sistem } \\
\text { Icon }\end{array}$ & $\begin{array}{l}\text { Sosial } \\
\text { Media } \\
\text { Link }\end{array}$ & $\begin{array}{c}\text { Nomor } \\
\text { telefon } \\
\text { dan } \\
\text { Chating } \\
\text { Online } \\
\end{array}$ & $\begin{array}{c}\text { Toko } \\
\text { finde } \\
\text { r }\end{array}$ & $\begin{array}{l}\text { Trust } \\
\text { mark }\end{array}$ & $\begin{array}{l}\text { JUM } \\
\text { LAH }\end{array}$ \\
\hline Lazada & 0,005 & 0,040 & 0,000 & 0,003 & 0,006 & 0,034 & 0,010 & 0,002 & 0,009 & 0,002 & 0,001 & 0,001 & 0,114 \\
\hline Tokopedia & 0,005 & 0,000 & 0,038 & 0,007 & 0,003 & 0,001 & 0,003 & 0,009 & 0,002 & 0,016 & 0,016 & 0,000 & 0,099 \\
\hline Shopee & 0,005 & 0,028 & 0,001 & 0,003 & 0,008 & 0,020 & 0,006 & 0,002 & 0,012 & 0,002 & 0,000 & 0,000 & 0,086 \\
\hline Bukalapak & 0,005 & 0,001 & 0,025 & 0,008 & 0,003 & 0,001 & 0,003 & 0,011 & 0,002 & 0,000 & 0,000 & 0,000 & 0,058 \\
\hline
\end{tabular}




\begin{tabular}{|c|c|c|c|c|c|c|c|c|c|c|c|c|c|}
\hline Blibli & 0,003 & 0,021 & 0,002 & 0,004 & 0,005 & 0,013 & 0,008 & 0,003 & 0,000 & 0,000 & 0,000 & 0,000 & 0,060 \\
\hline Zalora & 0,007 & 0,001 & 0,016 & 0,005 & 0,003 & 0,003 & 0,003 & 0,000 & 0,000 & 0,000 & 0,000 & 0,000 & 0,040 \\
\hline Hijup & 0,005 & 0,014 & 0,002 & 0,003 & 0,008 & 0,007 & 0,000 & 0,000 & 0,000 & 0,000 & 0,000 & 0,000 & 0,038 \\
\hline JD.id & 0,007 & 0,001 & 0,010 & 0,008 & 0,003 & 0,000 & 0,000 & 0,000 & 0,000 & 0,000 & 0,000 & 0,000 & 0,029 \\
\hline Elevenia & 0,003 & 0,011 & 0,005 & 0,003 & 0,000 & 0,000 & 0,000 & 0,000 & 0,000 & 0,000 & 0,000 & 0,000 & 0,021 \\
\hline Bhinneka & 0,009 & 0,003 & 0,004 & 0,000 & 0,000 & 0,000 & 0,000 & 0,000 & 0,000 & 0,000 & 0,000 & 0,000 & 0,016 \\
\hline $\begin{array}{l}\text { Qoo10 } \\
\text { Indonesia }\end{array}$ & 0,004 & 0,005 & 0,000 & 0,000 & 0,000 & 0,000 & 0,000 & 0,000 & 0,000 & 0,000 & 0,000 & 0,000 & 0,009 \\
\hline
\end{tabular}

Dari tabel 10 diatas didapatkan hasil perangkingan kelayakan e-commerce yang disajikan pada tabel 11.

Tabel 11. Urutan Rangking

\begin{tabular}{ccc}
\hline Peringkat & Alternatif & Hasil Akhir \\
\hline 1 & Lazada & 0,114 \\
\hline 2 & Tokopedia & 0,099 \\
\hline 3 & Shopee & 0,086 \\
\hline 4 & Blibli & 0,060 \\
\hline 5 & Bukalapak & 0,058 \\
\hline 6 & Zalora & 0,040 \\
\hline 7 & Hijup & 0,038 \\
\hline 8 & JD.id & 0,029 \\
\hline 9 & Elevenia & 0,021 \\
\hline 10 & Bhinneka & 0,016 \\
\hline 11 & Qoo10 Indonesia & 0,009 \\
\hline
\end{tabular}

Analisa Pada tabel 10 diatas dapat dilihat bahwa penelitian dengan menggunakan metode AHP, layanan e-commerce yang direkomendasikan untuk konsumen dari urutan tertinggi sampai terendah adalah Lazada - Tokopedia -ShopeeBlibli - Bukalapak - Zalora - Hijup - JD.id Elevenia - Bhinneka - Qoo10 Indonesia

\section{KESIMPULAN}

1. Hasil penelitian menunjukkan bahwa $e$ commerce yang bisa direkomendasikan kepada konsumen dalam melakukan transaksi jual beli online dari prioritas tinggi ke rendah adalah Lazada - Tokopedia - Shopee - Blibli Bukalapak - Zalora - Hijup - JD.id - Elevenia Bhinneka - Qoo10 Indonesia.

2. Nilai CR atau Consistensi Ratio $=-0,018$ yang artinya nilai konsistensi sudah optimal karena bernilai $<=0,1$.

\section{DAFTAR PUSTAKA}

Anton Setiawan. 2010. Implementasi Metode Analytical Hierarchy Process Untuk
Pengambilan Keputusan Pemilihan Foto Berdasarkan Tujuan Perolehan Foto. Jurnal Angkasa. Vol.2, No.1, April 2010.

Fadel Retzen Lupi. 2015. Analisis Strategi Pemasaran Dan Penjualan E-Commerce

Pada Tokopedia.Com. Jurnal Elektronik Sistem Informasi Komputer. Vol.2 No.1 Januari-Juni 2016.

Fajar, Bayu dan Beta. 2012. Sistem Pendukung Keputusan Evaluasi Pemilihan Pemenang Pengadaan Aset dengan Metode Simple Additive Weighting (SAW). Jurnal Sistem Informasi dan Bisnis.On-line : http://ejournal.undip.ac.id/index.php/jsinbis

Faisal, Silvester . Sistem Penunjang Keputusan Pemilihan Sekolah Menengah Kejuruan Teknik Komputer dan Jaringan yang Terfavorit dengan Menggunakan Multi-Criteria Decision Making. Jurnal Teknologi Informasi dan Ilmu Komputer (JTIIK). Vol.2, No. 1, April 2015, hlm. 11-19.

Kotler, Philip. 1998. Manajemen Pemasaran; Analisis, Perencanaan, Implementasi, dan Kontrol. Jakarta: Prehallindo.

Mahir Pradana. 2015. Klasifikasi Bisnis E-commerce Di Indonesia . MODUS Vol. 27 (2), 2015.

Permadi, Bambang S. 1992, AHP, Jakarta, Pusat Antar Universitas - Studi Ekonomi Universitas Indonesia.

Shabur, Heru, dan Riyadi. 2015. Implementasi ECommerce Sebagai Media Penjualan Online (Studi Kasus Pada Toko Pastbrik Kota Malang). Jurnal Administrasi Bisnis (JAB).Vol. 29 No. 1 Desember 2015.

Supriyono,Wisnu, Sudaryo. 2007. Sistem Pemilihan Pejabat Struktural Dengan Metode Ahp. Seminar Nasional I Sdm Teknologi Nuklir Yogyakarta, 21 - 22 November 2007. Issn 1978-0176

Turban, Efraim.; Aronson, Jay E. 2001. Decision Support Systems and Intelligent Systems, Sixth Edition, New Jersey, Prentice-Hall, Inc. 